\title{
Türkiye'de Üstün Zekâlılar ve Özel Yetenekliler Konusunda Yürüitülmüş Tezlerin Tematik İncelenmesine Yönelik Bir Çalışma
}

\section{A Study on the Thematic Investigation of Conducted Theses on Gifted and Talented Students in Turkey}

\author{
Hakan Şevki AYVACI ${ }^{1}$, Gürhan BEBEK ${ }^{2}$
}

• Geliş Tarihi: $07.05 .2018 \bullet$ Kabul Tarihi: 06.09.2018• Yayın Tarihi: 01.01.2019

\section{$\ddot{\mathbf{O} z}$}

Bu çalışmanın amacı, 2010 yılından itibaren üstün zekâlılar ve özel yetenekliler alanında yürütülmüş olan çalışmaları yıl, tür, konu, yaklaşım, model, örneklem, veri toplama aracı ve sonuçlar şeklinde 7 farklı başlık altında incelemek ve bu konu alanında araştırma yürütmeyi planlayan araştırmacılara yol göstermektir. Bu amaç doğrultusunda toplam 154 izinli teze ulaşılmış ve araştırma doküman analizi yöntemi kullanılarak yürütülmüştür. Üstün zekâlılar ve özel yetenekliler konusunda yürütülmüş tezlerin $\% 68,83$ 'ünün yüksek lisans $\% 31,17$ 'sinin doktora türünde olduğu ve yaklaşık \%55,84'ünün $(n=86)$ nicel yaklaşım, \%25,97'sinin $(n=40)$ nitel yaklaşım ve \%18,18'inin $(n=28)$ karma yaklaşım ile yürütüldüğü belirlenmiştir. Tüm çalışmalar göz önüne alındığında üstün zekâlılar ve özel yetenekli bireylerin özellikleri ve becerileri konusuna yönelik çalışmaların en yüksek orana sahip olduğu ve yöntem bağlamında Survey yönteminin ilk sırada geldiği görülmektedir. Araştırma türü olarak yüksek lisans tezlerinin oran ağırlı̆̆ının doktora tezlerine daha fazla olmasına bağlı olarak üstün zekâlılar ve özel yetenekliler konusunda doktora seviyesinde çalışmalar yapılması önerilmektedir.

Anahtar sözcükler: Üstün zekâlı ve özel yetenekli öğrenciler, yürütülen tezler, tematik inceleme

\begin{abstract}
This study aims at analyzing theses in the field of gifted and talented students with gifted and special abilities in terms of several variables, and guiding future researchers who are planning to carry out studies in the related topic. For this purpose, a total of 154 theses were reached and carried out using the research document analysis method. It was determined that $68,83 \%$ of the postgraduate thesis composed of master thesis while $31,17 \%$ of them were doctoral dissertation and it was concluded that $55,84 \%$ of the studies $(n=86)$ adopted quantitative approach while $25,97 \%$ of them $(n=40)$ qualitative and $18,18 \%$ of them $(n=28)$ mixed type. Considering the entire thesis under the descriptive researches theme, it was seen that researchers mostly preferred surveys studies. Consequently, due to the lack of studies at doctoral level compared to master, it is suggested to conduct doctoral dissertations on students with gifted and special abilities.
\end{abstract}

Keywords: Gifted and Talented Students, conducted theses, thematic investigation

\section{Önerilen Atıf Bilgisi:}

Ayvacı, H.Ş. ve Bebek, G.(2019). Türkiye'de üstün zekâlılar ve özel yetenekliler konusunda yürütülmüş tezlerin tematik incelenmesine yönelik bir çalışma. Pamukkale Üniversitesi Eğitim Fakültesi Dergisi, 45, 267-292.

\footnotetext{
${ }^{1}$ Prof. Dr., Trabzon Üniversitesi, ORCİD: 0000-0002-3181-3923, hsayvaci@gmail.com

2 Doktora Öğrencisi, Trabzon Üniversitesi, ORCİ: 0000-0003-4862-5782, gurhan.bebek@gmail.com
} 


\section{Giriş}

Bilim-ürün-maddiyat döngüsünü anlamlı ve doğru bir şekilde kullanmak isteyen toplumlar, bilişsel, duyuşsal ve psikomotor açıdan donanımlı (Levent, 2011), karşılaştıkları problemlere çözümler üretebilen, problemlere çözüm üretme sürecinde yaratıcılık ve özgünlük kıstaslarını göz önünde bulunduran ve var olan bilimsel bilgilerden yararlanarak yeni ürünler ortaya koymaya çalışan bireyler yetiştirme çabası içerisindedir. Toplumlara yön veren bireylerin "pasif çoğunluk" değil "aktif azınlık" adı verilen üstün zekâlı ve özel yetenekli öğrenciler arasından çıktığı; bu öğrencilerin yaratıcılık, üretkenlik ve liderlik gibi özelliklere, kendi yaşıtlarından daha ileri düzeyde anlama kapasitesine ve kavrama ve gözlemleme gibi yeterliklere sahip olmalarına bağlı olarak sahip oldukları yeteneklerin geliştirilmesine firsat vermek ve bilişsel kapasitelerini verimli bir şekilde kullanmalarını sağlamak ülkelerin bugünü ve geleceği açısından oldukça önemlidir (Cutts-Moseley, 2004). Bu önem durumu Amerikan Ulusal Üstün Yetenekli Çocuklar Birliği'nin üstün zekâlı ve özel yetenekli bireylere yönelik yaptığı tanımlamada da görülmektedir. Amerikan Ulusal Üstün Yetenekli Çocuklar Birliği'ne göre üstün zekâlı ve özel yetenekli birey; akademik anlamda özel entelektüel anlamda genel yeteneğe sahip, liderlik, yaratıcılık ve görsel sanat uygulamaları gibi alanlarda üst düzeyde performans sergileme potansiyeli olan ve bu potansiyeli ülkelerine olumlu yönde katkı sağlayabilmek için sergileyen kişi olarak tanımlamaktadır (National Association of Gifted Children, 2006).

Toplumların gelişimi ve değişimi için önemli bir yere sahip olan üstün zekâlı ve özel yetenekli bireyler ve eğitimlerine yönelik olarak dünya üzerindeki gelişimlere ülkemizde kayıtsız kalmamış 1993 yılında Milli Eğitim Bakanlığı (MEB) Özel Eğitim Rehberlik ve Danışma Hizmetleri Genel Müdürlüğü bünyesinde Bilim Sanat Merkezleri (BİLSEM) kurulmuştur (Tebliğler Dergisi, 2001). BİLSEM'ler temel amaç olarak üstün zekâlı ve özel yetenekli öğrencilerin; sahip olduğu zihinsel aktivite kapasitelerinin ve yeteneklerinin erken yaşta fark edilerek geliştirilmesi, sahip oldukları özelliklerin farkında olmalarının sağlanması ve kapasitelerini geliştirerek sahip oldukları becerileri en üst düzeyde kullanmalarını sağlamayı hedef edinmiştir (MEB, 2013). Bunun yanı sıra üstün zekâlı ve özel yetenekli öğrencilerden bilimsel düşünce ve davranışlarla estetik değerleri birleştirme, üretken olma, sorun çözme, kendini gerçekleştirmiş birey olarak yetişme, teknik buluşlar yapma ve çağdaş araçlar geliştirebilme gibi beklentilerde bulunmaktadır. Bu beklentileri karşılamak adına BİLSEM'lerde Oryantasyon (Uyum-Uyarlama), Destek Eğitim, İletişim, Bireysel Yetenekleri Fark Ettirme ve Özel Yetenekleri Geliştirme (MEB, 2015) gibi eğitim programları bulunmaktadır. Bu programlar ile birlikte öğrencilerin eğitim görmekte oldukları okullarda toplumsal bütünleşme, BİLSEM'ler aracılığıyla da yeteneklerini fark etmeleri ve bu yeteneklerinin geliştirilmesine yönelik eğitim almaları sağlanmaktadır (Çamdeviren, 2014). Bu bağlamda da bilimsel çalışma disiplini kazanmış, disiplinler arası düşünme yeteneğine sahip, günlük hayat problemlerini çözme ya da belirlenen ihtiyaçları karşılamaya yönelik projeler gerçekleştirebilen bireyler olan üstün zekâlı ve özel yetenekli öğrenciler için çeşitli değişkenler açısından çalışmaların yürütülmesi gerektiğini söylemek pek yanlış olmayacaktır.

Literatür incelendiğinde üstün zekâlı ve özel yetenekli bireyler için bütünleştirilmiş (VanTassel-Baskbura \& Wood, 2009), paralel (Tomlinson, 2009), WISC (Sternberg, 2009), sınırsız yetenek (Schlichter, 2009), üçlü zenginleştirme (Reis \& Renzulli, 2010), otonom (Betts \& Kercher, 2009) ve mükemmelik (Assouline ve diğerleri, 2009) gibi eğitsel modellerin 


\section{Türkiye’de Üstün Zekâlılar ve Özel Yetenekliler Konusunda Yürütülmüş Tezlerin Tematik}

İncelenmesine Yönelik Bir Çalışma

geliştirildiği; üstün zekâlı ve özel yetenekli öğrenciler için hazırlanan farklılaştırılmış eğitimsel modellerin etkililiğinin araştırıldığı (Boerger, 2005; Çalıkoğlu, 2014; Gould, Weeks \& Evans, 2003; Gür, 2006; Kanl1, 2008; Karabey, 2010; Liu \& Lederman, 2002; Öğretme, 2004; Özyaprak, 2012; Sondergeld \& Schultz, 2008; Stake \& Mares, 2001; Tyler-Wood, 2000; Watters \& Diezmann, 2000) yeni modellerin önerildiği (Yılmaz Atik, 2007) ve kullanılan modellerin üstün zekâlı ve yetenekli öğrencilerin akademik başarılarını (Altun, 2010; Atalay, 2014; Gross \& van Vliet, 2012; Öğretme, 2004; Springer, Pugalee \& Algozzine, 2007; Stager, 2006; Steenbergen-Hu \& Moon, 2011; Şahin, 2016; Ünlü, 2009; Wood, 2006), problem çözme becerilerini (Durma, 2014; Kanl1, 2008; Karabey, 2010; Sıdar, 2011), bilimsel süreç becerilerini (Özdemir; 2017; VanTassel-Baska, Bass, Ries, Poland \& Avery, 1998; Vural, 2010), yaratıc1 düşünme becerilerini (Batdal Karaduman, 2012; Emir, 2013; Kanl1, 2008; Kaplan Say1, 2013; Kök, 2012; Özyaprak, 2012), epistemolojik inançlarını (Aşut, 2013; Liu \& Lederman, 2002; Schommer \& Dunnell, 1997), fen bilimlerine veya fen bilimleri ile ilgili mesleklere olan tutumunu (Camc1 Erdoğan ve Kahveci, 2015; Melber, 2003; Özdemir, 2014; Stake \& Mares, 2001; Ürek, 2012) ve bilime yönelik tutumunu (Kemaneci, 2012; Keser, 2012; Stake \& Mares, 2001) geliştirip geliştirmediğine yönelik çeşitli çalışmaların yürütüldüğü görülmektedir. Ayrıca üstün zekâlılar ve özel yetenekliler konusunda yürütülen araştırmaları inceleyen çalışmalara da (Coşkun, Dündar ve Parlak, 2014; Dönmez ve İdin, 2017; Koç ve Saranl1, 2017; Güçin ve Oruç, 2015; Özenç ve Özenç, 2013) az da olsa rastlanmaktadır.

Ancak literatür taraması şeklinde yürütülen bu araştırmalarda tercih edilen anahtar kelime faktörü ve ele alınan faktörlerden kaynaklı olarak değişkenlerin içeriği açısından eksiklikler bulunmaktadır. Bu durum ülkemizde üstün zekâlılar ve özel yetenekliler konusunda yürütülen çalışmaların belirli çerçeveler dışına çıkamamasına neden olmuştur. Ayrıca ortaya çıkarılan durumun ilerleyen zamanlarda yürütülecek olan çalışmalara etki edeceği ve benzer perspektifler içerisinde kalacağı düşünüldüğünde; üstün zekâlılar ve özel yetenekliler konusunda yürütülen çalışmaların derinlemesine irdelenmesi ve bu irdeleme temeliyle birlikte ilerleyen yıllarda yürütülecek olan çalışmalara bir literatür desteği sağlanması hem konu alanının genişletilmesi hem de orijinal araştırmaların ortaya çıkartılması açısından oldukça önemlidir. Bu bağlamda araştırmada, 2010 yılından itibaren üstün zekâlılar ve özel yetenekliler alanında yürütülmüş olan çalışmaları yıl, tür, konu, yaklaşım, model, örneklem, veri toplama aracı ve sonuçlar şeklinde 7 farklı başlık altında incelemek ve bu konu alanında araştırma yürütmeyi planlayan araştırmacılara yol göstermek amaçlanmaktadır.

\section{Yöntem}

Araştırmanın yöntem başlığı altında araştırmanın modeli, evren ve örneklem, veri toplama süreci ve analizi ile geçerlik ve güvenirlik çalışmaları hakkında bilgiler verilmektedir.

\section{Araştırmanın Modeli}

Nitel yaklaşıma dayalı olarak yürütülen araştırmada doküman analizi yöntemi tercih edilmiştir. Doküman analizi yöntemi, araştırma konusuna yönelik olarak mevcut kayıtları ve belgeleri toplama ve buna bağlı olarak belirli normların ve kalıpların kullanılarak kodlanması işlemine verilen isimdir (Çepni, 2010). Araştırma kapsamında da 2010 yılından itibaren üstün zekâlılar ve özel yetenekliler alanında yürütülmüş olan çalışmaları çeşitli değişkenler açısından 
incelenmesi ve bu konu alanında araştırma yürütmeyi planlayan araştırmacılara yol göstermesi amaçladığından bu yöntem uygun görülmüştür.

\section{Evren ve Örneklem}

"Üstün zekâlı”, “Üstün yetenekliler” ve "Özel yetenekliler” anahtar kavramları kullanılarak Yükseköğretim Kurulu Ulusal Tez Merkezi'nde yayımlanan tezler üzerinden araştırma yürütülmüştür. Toplamda 154 tane teze ulaşılmıştır. Bu tezlerin 15 tanesi 2010 yılına, 8 tanesi 2011 y1lına, 14 tanesi 2012 y1lına, 15 tanesi 2013 y1lına, 24 tanesi 2014 y1lına, 28 tanesi 2015 yılına, 27 tanesi 2016 yılına ve 23 tanesi 2017 yılına aittir. Araştırma kapsamında üstün zekâlılar ve özel yetenekliler konusunda yürütülmüş olan tezler kronolojik sıraya uygun olmak üzere araştırmanın yılı, araştırmanın türü, araştırmanın adı, araştırmacının adı ve araştırmanın yürütüldügü kurum başlıkları ile birlikte Ek-1'de gösterilmiştir.

\section{Veri Toplama Süreci ve Analizi}

Araştırmanın amacı doğrultusunda ulaşılan çalışmalarda yıl, tür, konu, yaklaşım, model, örneklem, veri toplama aracı ve sonuçlar şeklinde 7 tema üzerinden analizler yürütülmüştür. Yürütülen analizler içerik analizinin türlerinden birisi olan tematik analiz uygulamasına aittir. Tematik analiz, belirlenen bir amaç doğrultusunda yürütülen çalışmaların toplanıp çeşitli değişkenler açısından irdelenmesi ve verilerin tanılayıcı bir şekilde değerlendirilmesini içeren bir uygulamadır (Çalık ve Sözbilir, 2014). Araştırma kapsamında da üstün zekâlılar ve özel yetenekliler alanında yürütülen çalışmaların yıl, tür, konu, yaklaşım, model, örneklem, veri toplama aracı ve sonuçlar şeklinde 7 tema altında incelenmesinin planlanması nedeniyle bu uygulama uygun görülmüştür.

\section{Geçerlik ve Güvenirlik Çalışmaları}

Araştırmanın geçerlik faktörüne yönelik olarak iç ve dış geçerlik kıstasları göz önüne alınmıştır. Araştırmanın iç geçerlik kıstası için araştırmacılar tarafından üye kontrol işlemi gerçekleştirilmiştir. Üye kontrol işlemi yürütülen çalışmaların doğru ve sistemli bir şekilde kategorize edilip edilmediğini ve tekrar eden kaynağın olup olmadığını ortaya çıkarmaktadır (Cohen, Manion ve Morrison, 2000). Bu bağlamda da araştırmacılar tarafindan üye kontrol işlemi gerçekleştirilerek iç geçerlik sağlanmaya çalışılmıştır. Araştırmanın dış geçerlik faktörünü sağlama adına da verilerin analiz işleminde özgün ve yaratıcı kategorilerin oluşturulması hususu göz önüne alınmıştır.

Araştırmanın güvenirlik faktörü için;

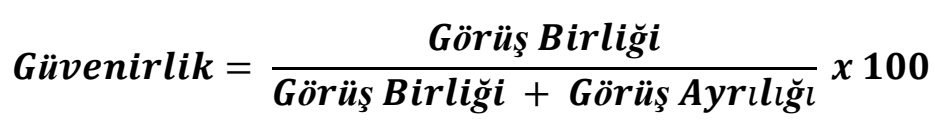

matematiksel modeli uygulanmıştır. Bu modele olarak yapılan ölçüm sonucunda uyuşum yüzdesi \%78 olarak hesaplanmıştır. Bu yüzdeye yönelik olarak Miles ve Huberman (1994) "Güvenirlik yüzdesi \%70'in üzerinde olmalıdır. \%70'in üzerinde olan eşleştirmelerin güvenirliği bulunmaktadır” (Miles ve Huberman, 1994'den akt., Yüksel, 2011) ifadesine göre araştırmanın güvenirliği sağlanmaya çalışılmıştır. 
Türkiye'de Üstün Zekâlılar ve Özel Yetenekliler Konusunda Yürütülmüş Tezlerin Tematik İncelenmesine Yönelik Bir Çalışma

\section{Bulgular}

2010 yılı itibariyle üstün zekâlılar ve özel yetenekliler alanında yürütülmüş olan çalışmaları çeşitli değişkenler açısından incelemek ve bu konu alanında araştırma yürütmeyi planlayan araştırmacılara yol göstermenin amaçlandığı bu çalışmada 154 tane tez yıl ve tür, konu, yıl ve yaklaşım, yöntem ve model, örneklem seçimi, veri toplama aracı ve sonuçlar olmak üzere 7 tema üzerinden incelenmiştir.

Birinci tema, üstün zekâlılar ve özel yetenekliler konusunda yürütülmüş tezlerin yıllarına ve türlerine göre dağılımının göstergesidir. $\mathrm{Bu}$ bağlamda Tablo 1'de araştırmanın yılı ve araştırmanın türü başlığına bağlı olarak frekans ve yüzdelik değerleri gösterilmiştir.

Tablo 1. Üstün Zekâlılar ve Özel Yetenekliler Konusunda 2010 Yılından İtibaren Yürütülmüş Tezlerin Yıllarına ve Türlerine Göre Dağılımı

\begin{tabular}{|c|c|c|c|c|c|c|}
\hline \multirow{3}{*}{ Araştırma Y1lı } & \multirow{3}{*}{$\mathrm{f}$} & \multirow{3}{*}{$\%$} & \multicolumn{4}{|c|}{ Araştırma Türü } \\
\hline & & & \multicolumn{2}{|c|}{ Yüksek Lisans } & \multicolumn{2}{|c|}{ Doktora } \\
\hline & & & $\mathbf{f}$ & $\%$ & f & $\%$ \\
\hline 2010 & 15 & 9,74 & 12 & 7,79 & 3 & 1,94 \\
\hline 2011 & 8 & 5,19 & 6 & 3,89 & 2 & 1,29 \\
\hline 2012 & 14 & 9,09 & 9 & 5,84 & 5 & 3,24 \\
\hline 2013 & 15 & 9,74 & 10 & 6,49 & 5 & 3,24 \\
\hline 2014 & 24 & 15,58 & 14 & 9,09 & 10 & 6,49 \\
\hline 2015 & 28 & 18,18 & 21 & 13,63 & 7 & 4,54 \\
\hline 2016 & 27 & 17,53 & 15 & 9,74 & 12 & 7,79 \\
\hline 2017 & 23 & 14,93 & 19 & 12,33 & 4 & 2,59 \\
\hline TOPLAM & 154 & 100 & 106 & 68,83 & 48 & 31,17 \\
\hline
\end{tabular}

Tablo 1 incelendiğinde, 2010 y1lında yürütülmüş 15 tezin 12'sinin yüksek lisans 3'ünün doktora türünde olduğu; 2011 yılında yürütülmüş 8 tezin 6'sının yüksek lisans 2'sinin doktora türünde olduğu; 2012 yılında yürütülmüş 14 tezin 9'unun yüksek lisans 5'inin doktora türünde olduğu; 2013 y1lında yürütülmüş 15 tezin 10'unun yüksek lisans 5'inin doktora türünde olduğu; 2014 y1lında yürütülmüş 24 tezin 14'ünün yüksek lisans 10'unun doktora türünde olduğu; 2015 y1lında yürütülmüş 28 tezin 21'inin yüksek lisans 7'sinin doktora türünde olduğu; 2016 yılında yürütülmüş 26 tezin 14'ünün yüksek lisans 12'sinin doktora türünde olduğu; 2017 yılında yürütülmüş 23 tezin 19'unun yüksek lisans 4'ünün doktora türünde olduğu görülmüştür. Bu bağlamda konu alanında yürütülmüş tezlerin \%68,83'ünün yüksek lisans \%31,17'sinin doktora türünde olduğu belirlenmiştir. Ayrıca üstün zekâlılar ve özel yetenekliler konusunda yürütülmüş tezlerin türleri arasında yüksek lisans lehine ağırlığın olduğu görülmüss sadece 2014 yılında tezlerin türleri arasındaki oranda yakınlaşma olduğu belirlenmiştir.

İkinci tema, üstün zekâlılar ve özel yetenekliler konusunda 2010 y1lından itibaren yürütülmüş tezlerin konusuna göre dağılımının göstergesidir. Bu bağlamda Tablo 2'de araştırmanın konusuna bağlı olarak frekans ve yüzdelik değerleri gösterilmiştir. 
Tablo 2. Üstün Zekâlılar ve Özel Yetenekliler Konusunda 2010 Yılından İtibaren Yürütülmüş Tezlerin Konularına Göre Dağılımı

\begin{tabular}{lll}
\hline Araştırmanın Konusu & f & \% \\
\hline Üstün Zekâlı ve Özel Yetenekli Bireyler ve Etkinlik - Uygulama & 13 & 8,44 \\
\hline Üstün Zekâlı ve Özel Yetenekli Bireyler ve Program - Model & 20 & 12,98 \\
\hline Üstün Zekâlı ve Özel Yetenekli Bireyler ve Yöntem - Yaklaşım & 11 & 7,14 \\
\hline Üstün Zekâlı ve Özel Yetenekli Bireyler ve Eğitim-Öğretim Süreci & 4 & 2,59 \\
\hline Üstün Zekâlı ve Özel Yetenekli Bireylerin Özellikleri ve Becerileri & 27 & 17,53 \\
\hline Üstün Zekâlı ve Özel Yetenekli Bireyler ve Tutumları & 12 & 7,79 \\
\hline Üstün Zekâlı ve Özel Yetenekli Bireyler ve Gereksinimleri & 4 & 2,59 \\
\hline Üstün Zekâlı ve Özel Yetenekli Bireyler ve Karşısştıkları Sorunlar & 3 & 1,94 \\
\hline Üstün Zekâlı ve Özel Yetenekli Bireyler ve Aileleri & 8 & 5,19 \\
\hline Üstün Zekâlı ve Özel Yetenekli Bireyler ve Öğretmenler & 14 & 9,09 \\
\hline Üstün Zekâlı ve Özel Yetenekli Bireylerin Belirlenmesi & 3 & 1,94 \\
\hline Üstün Zekâlı ve Özel Yetenekli Bireyler ve Zihinsel Modeller & 6 & 3.89 \\
\hline Üstün Zekâlı ve Özel Yetenekli Bireyler ve Tarihsel Süreç - Literatür & 6 & 3.89 \\
\hline Üstün Zekâlı ve Özel Yetenekli Bireyler ve Fen Eğitimi & 8 & 5,19 \\
\hline Üstün Zekâlı ve Özel Yetenekli Bireyler ve Olmayan Bireyler & 8 & 5,19 \\
\hline Üstün Zekâlı ve Özel Yetenekli Bireyler ve BíLSEM & 7 & 4,54 \\
\hline
\end{tabular}

Tablo 2 incelendiğinde, üstün zekâlılar ve özel yetenekliler konusunda yürütülmüş tezlerin 13 tanesinin etkinlik ve uygulama konularında; 20 tanesinin program ve model oluşturma konularında; 11 tanesinin yöntem ve yaklaşım geliştirme konularında; 4 tanesinin eğitim-öğretim sürecine yönelik konularda; 27 tanesinin özellikler ve beceriler konularında; 12 tanesinin tutumlar konusunda; 4 tanesinin gereksinimler ya da ihtiyaçlar konusunda; 3 tanesinin karşılaştıkları sorunlar konusunda; 8 tanesinin ebeveynler ya da aileler ile ilgili konuda; 14 tanesinin öğretmenler konusunda; 3 tanesinin bireyleri belirleme sürecinde; 6 tanesinin bireylerin sahip olduğu zihinsel modellerin ortaya çıkarılmasında; 6 tanesinin tarihsel süreç içerisindeki değişim ve literatür konusunda; 8 tanesinin fen eğitimi konusunda; 8 tanesinin karşılaştırmalı olarak üstün zekâlılar ve özel yetenekliler ve olmayanlar konusunda ve 7 tanesinin BİLSEM'ler üzerine yürütüldüğü görülmüştür. Üstün zekâlılar ve özel yetenekli bireylerin özellikleri ve becerileri konusuna yönelik çalışmaların diğer çalışmalar arasında en yüksek orana sahip olduğu, üstün zekâl1lar ve özel yetenekli bireylerin belirlenmesine yönelik çalışmaların ise diğer çalışmalardan daha düşük orana sahip olduğu belirlenmiştir. Ayrıca üstün zekâlılar ve özel yeteneklilere yönelik program geliştirme ve model geliştirme, etkinlik ve uygulama tasarlama ve yeni bir yöntem ve yaklaşım oluşturma konularına azımsanmayacak bir oranda değinildiği de gözler önüne serilmektedir.

Üçüncü tema, üstün zekâlılar ve özel yetenekliler konusunda 2010 yllından itibaren yürütülmüş tezlerin yıllarına ve yaklaşımına göre dağılımının göstergesidir. Bu bağlamda Tablo 3'te araştırmanın yılı ve araştırmanın yaklaşımı başlığına bağlı olarak frekans ve yüzdelik değerleri gösterilmiştir. 
Türkiye'de Üstün Zekâlılar ve Özel Yetenekliler Konusunda Yürütülmüş Tezlerin Tematik İncelenmesine Yönelik Bir Çalışma

Tablo 3. Üstün Zekâlılar ve Özel Yetenekliler Konusunda 2010 Yılından İtibaren Yürütülmüş Tezlerin Yıllarına ve Yaklaşımlarına Göre Dağılımı

\begin{tabular}{lllllll}
\hline \multirow{2}{*}{ Araştırmanın Yili } & \multicolumn{2}{l}{ Nicel Yaklaşım } & \multicolumn{2}{l}{ Nitel Yaklaşım } & \multicolumn{2}{c}{ Karma Yaklaşım } \\
\cline { 2 - 7 } & $\mathrm{f}$ & $\%$ & $\mathrm{f}$ & $\%$ & $\mathrm{f}$ & $\%$ \\
\hline 2010 & 7 & 4,54 & 7 & 4,54 & 1 & 0,64 \\
\hline 2011 & 5 & 3,24 & 1 & 0,64 & 2 & 1,29 \\
\hline 2012 & 8 & 5,19 & 1 & 0,64 & 5 & 3,24 \\
\hline 2013 & 9 & 5,84 & 2 & 1,29 & 4 & 2,59 \\
\hline 2014 & 15 & 9,74 & 6 & 3,89 & 3 & 1,94 \\
\hline 2015 & 17 & 11,03 & 4 & 2,59 & 7 & 4,54 \\
\hline 2016 & 13 & 8,44 & 9 & 5,84 & 5 & 3,24 \\
\hline 2017 & 12 & 7,79 & 10 & 6,49 & 1 & 0,64 \\
\hline TOPLAM & 86 & 55,84 & 40 & 25,97 & 28 & 18,18 \\
\hline
\end{tabular}

Tablo 3 incelendiğinde, üstün zekâlılar ve özel yetenekliler konusunda 2010 yılında yürütülmüş çalışmaların 7 tanesinin nicel, 7 tanesinin nitel ve 1 tanesinin karma; 2011 yılında yürütülmüş çalışmaların 5 tanesinin nicel, 1 tanesinin nitel ve 2 tanesinin karma; 2012 yılında yürütülmüşş çalışmaların 8 tanesinin nicel, 1 tanesinin nitel ve 5 tanesinin karma; 2013 y1lında yürütülmüş çalışmaların 9 tanesinin nicel, 2 tanesinin nitel ve 4 tanesinin karma; 2014 yılında yürütülmüş çalışmaların 15 tanesinin nicel, 6 tanesinin nitel ve 3 tanesinin karma; 2015 yılında yürütülmüş çalışmaların 17 tanesinin nicel, 4 tanesinin nitel ve 7 tanesinin karma; 2016 yılında yürütülmüş çalışmaların 13 tanesinin nicel, 9 tanesinin nitel ve 5 tanesinin karma; 2017 yılında yürütülmüş çalışmaların 11 tanesinin nicel, 10 tanesinin nitel ve 1 tanesinin karma yaklaşım temasında olduğu görülmektedir. Üstün zekâlılar ve özel yetenekliler konusunda 2010 yılından itibaren yürütülmüş 154 tane tez göz önüne alındığında yaklaşı \%55,84'ünün $(n=86)$ nicel yaklaşım, \%25,97'sinin $(n=40)$ nitel yaklaşım ve \%18,18'inin $(n=28)$ karma yaklaşım ile yürütüldüğü belirlenmiştir. Ayrıca 2016 ve 2017 yılları haricinde yürütülmüş olan tezlerde nicel yaklaşımın nitel yaklaşım ve karma yaklaşıma oranla daha yüksek bir orana sahip olduğu ortaya çıkarılmıştır.

Dördüncü tema, üstün zekâlılar ve özel yetenekliler konusunda 2010 yılından itibaren yürütülmüş tezlerin yöntemleri ve modellerine göre dağılımının göstergesidir. Bu bağlamda Tablo 4'te araştırmanın yöntemi ve araştırmanın modeli başlığına bağlı olarak frekans ve yüzdelik değerleri gösterilmiştir.

Tablo 4 incelendiğinde, üstün zekâlılar ve özel yetenekliler konusunda 2010 yılından itibaren yürütülmüş tezlerin betimsel araştırmalar, yorumlayıcı araştırmalar, analitik araştırmalar ve deneysel araştırmalar olmak üzere dört tema altında toplandığı görülmektedir. Betimsel araştırmalar; özel durum çalışması, survey (alan taraması), karşılaştırılmalı araştırma ve gelişimci araştırma yöntemlerini içermektedir. Yorumlayıcı araştırmalar; aksiyon araştırması, fenomenografik araştırma ve etnografik araştırma yöntemlerini içermektedir. Analitik araştırmar; doküman analizi ve tarihsel araştırma yöntemlerini içermektedir. Deneysel araştırmalar; basit deneysel araştırma, tam deneysel araştırma ve yarı deneysel araştırma yöntemlerini içermektedir. Tüm çalışmalar göz önüne alındığında betimsel araştırmalar başlığı altında bulunan Survey (alan taraması) yönteminin ilk sırada geldiği, karşılaştırmalı yöntemin ikinci sırayı aldığı ve özel durum çalışması yönteminin üçüncü sırada olduğu görülmektedir. Bu 
durum üstün zekâl1lar ve özel yetenekliler konusunda 2010 yllından itibaren yürütülmüş tezlerin daha çok betimsel araştırma teması altında olduğunu ortaya çıkarmıştır. Ayrıca yorumlayıcı araştırmalar teması altında bulunan etnografik araştırmalar yöntemi konusunda ise herhangi bir araştırmaya rastlanmamıştır.

Tablo 4. Üstün Zekâlılar ve Özel Yetenekliler Konusunda 2010 Yılından İtibaren Yürütülmüsş Tezlerin Yıllarına ve Yaklaşımlarına Göre Dağılımı

\begin{tabular}{lccc}
\hline \multirow{2}{*}{ Araştırmanın Yöntemi } & Araştırmanın Modeli & $\mathrm{f}$ & $\%$ \\
\hline \multirow{2}{*}{ BETİMSEL ARAŞTIRMALAR } & Özel Durum Çalışması & 27 & 17,53 \\
\cline { 2 - 4 } & Survey (Alan Taraması) & 48 & 31,16 \\
\cline { 2 - 4 } & Karşılaştırmalı Araştırma & 27 & 12,98 \\
\cline { 2 - 4 } YORUMLAYICI ARAŞTIRMALAR & Gelişimci Araştırma & 1 & 0,64 \\
\cline { 2 - 4 } & Aksiyon Araşırması & 5 & 3,24 \\
\cline { 2 - 4 } ANALITİK ARAŞTIRMALAR & Eenomenografik Araştırma & 3 & 1,94 \\
\cline { 2 - 4 } & Etnografik Araştırma & 0 & 0,00 \\
\hline \multirow{2}{*}{ DENEYSEL ARAŞTIRMALAR } & Doküman Analizi & 10 & 6,49 \\
\cline { 2 - 4 } & Basit Deneysel Araştırma & 3 & 1,94 \\
\cline { 2 - 4 } & Tam Deneysel Araştırtırma & 7 & 4,54 \\
\hline
\end{tabular}

Beşinci tema, üstün zekâlılar ve özel yetenekliler konusunda 2010 y1lından itibaren yürütülmüş tezlerin örneklem seçimine göre dağılımının göstergesidir. Bu bağlamda Şekil 1'de örneklem seçimine bağlı olarak frekans ve yüzdelik değerleri pasta dilimi şeklinde gösterilmiştir.

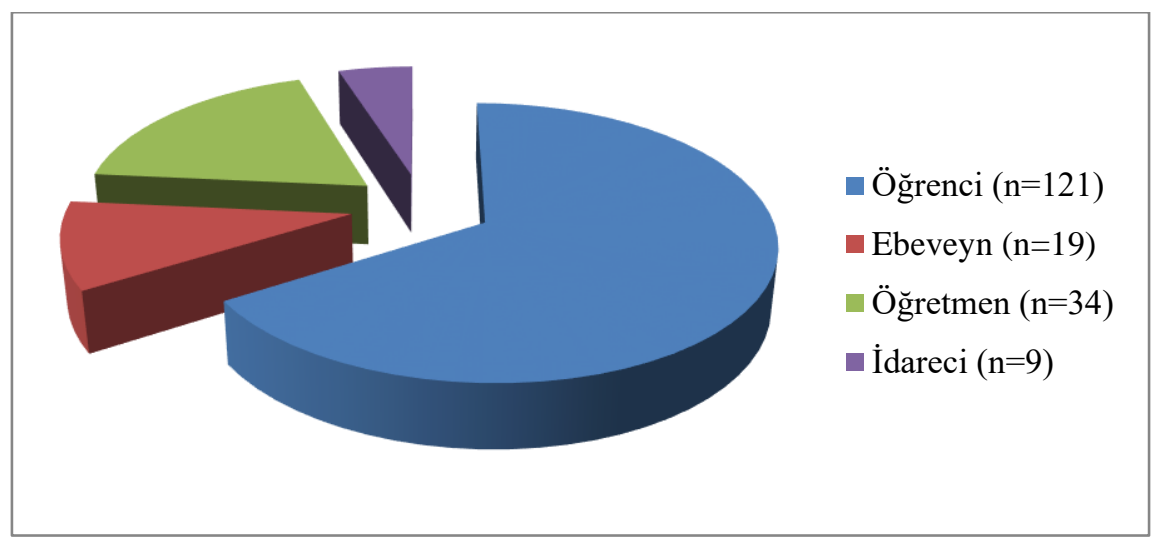

Şekill. Üstün zekâlılar ve özel yetenekliler konusunda 2010 yılından itibaren yürütülmüş̧ tezlerin örneklem seçimine göre dağılımı

Şekil 1 incelendiğinde, üstün zekâlllar ve özel yetenekliler konusunda 2010 yılından itibaren yürütülmüş tezlerde öğrenci, ebeveyn, öğretmen ve idareci olmak üzere 4 tema altında toplandığg görülmektedir. Şekildeki sayının toplam tez sayısından farklı olmasının nedeni bazı çalışmalarda iki farklı örneklem grubunun kullanılıyor olmasından kaynaklanmaktadır. 2010 yılından itibaren yürütülmüş tezlerin $\% 66,12$ 'si $(n=121)$ öğrenci temasında, \%10,38’i $(n=19)$ ebeveyn temasında, \%18,57'si $(n=34)$ öğretmen temasında ve \%5'i $(n=9)$ idareci temasında 
yürütüldüğü gözlenmiştir. Ayrıca öğrenciler üzerine yürütülen çalışmaların diğer türlerin toplamından da fazla olduğu gözler önüne serilmektedir.

Altıncı tema, üstün zekâlılar ve özel yetenekliler konusunda 2010 yılından itibaren yürütülmüş tezlerin veri toplama araçlarına göre dağılımının göstergesidir. Bu bağlamda Şekil 2 'de veri toplama araçlarına bağlı olarak frekans ve yüzdelik değerleri pasta dilimi şeklinde gösterilmiştir.

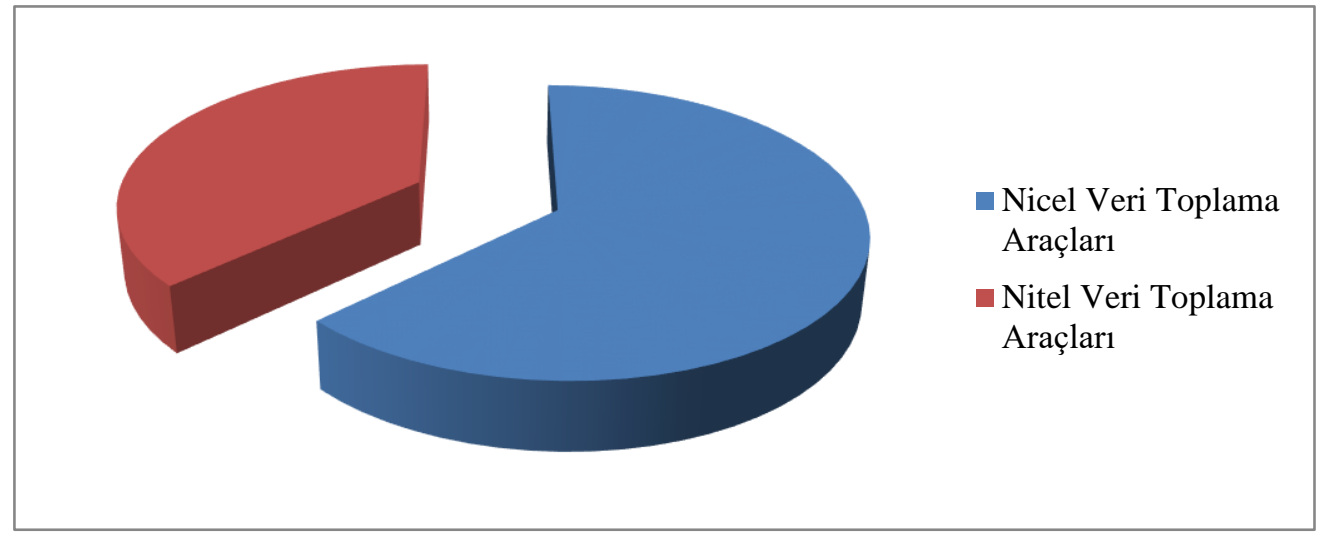

\section{Şekil2. Üstün zekâlılar ve özel yetenekliler konusunda 2010 yılından itibaren yürütülmüş tezlerin veri toplama araçlarına göre dağılımı}

Şekil 2 incelendiğinde, üstün zekâlllar ve özel yetenekliler konusunda 2010 yılından itibaren yürütülmüş olan tezlerde nitel ve nicel olmak üzere iki farklı temada veri toplama araçlarının kullanıldığ 1 tespit edilmiştir. Tezlerin 102 tanesinde nicel veri toplama araçlarının (\%62) 60 tanesinde ise nitel veri toplama araçlarının (\%38) kullandığı keşfedilmiştir. Nicel veri toplama araçları başlığı altında ölçek, test, anket ve envanterlerin; nitel veri toplama araçları başlığı altında ise gözlem ve mülakatın varlığı sonucu grafik oluşmuştur. Ayrıca araştırmanın karma yaklaşım şeklinde yürütüldügü araştırmalarda nicel ve nitel için ayrı ayrı veri toplama araçları göz önüne alınarak analiz işlemi tamamlanmıştır.

Yedinci tema, üstün zekâlılar ve özel yetenekliler konusunda 2010 yılından itibaren yürütülmüş tezlerin sonuçlarına göre dağılımının göstergesidir. Bu bağlamda Tablo 5'te araştırmaların sonuçlarına bağlı olarak frekans ve yüzdelik değerler gösterilmiştir.

Tablo 5 incelendiğinde, üstün zekâlılar ve özel yetenekliler konusunda 2010 yılından itibaren yürütülmüş tezlerin sonuçları; etkinliklerin üstün zekâlı ve özel yetenekli bireylerin yaratıcılığına etkisi, etkinliklerin üstün zekâlı ve özel yetenekli bireylerin başarısına etkisi, programların üstün zekâlı ve özel yetenekli bireylerin başarısına etkisi, yöntemlerin üstün zekâlı ve özel yetenekli bireylerin başarısına etkisi, yaklaşımların üstün zekâlı ve özel yetenekli bireylerin başarısına etkisi, üstün zekâlı ve özel yetenekli bireyler ile olmayanlar arasındaki farklar, üstün zekâlı ve özel yetenekli bireylerde demografik özelliklerin etkisi, üstün zekâlı ve özel yetenekli bireylere sahip olan ailelerin eğitim ihtiyac1, üstün zekâlı ve özel yetenekli bireylerin becerileri arasındaki ilişki, üstün zekâlı ve özel yetenekli bireyler için ölçme aracı geliştirme ihtiyacı ve üstün zekâlı ve özel yetenekli bireylere verilen eğitimin tarihsel gelişimi olmak üzere 12 farklı tema altında sınıflandırılmıştır. Üstün zekâlı ve özel yeteneklerin bireylerin becerileri arasındaki ilişkiyi bir sonuç olarak ortaya koyan çalışmalar yüzde 18,12 ile 
en yüksek orana sahiptir. Üstün zekâlı ve özel yetenekli bireylere verilen eğitimin tarihsel gelişiminin nasıl değiştiğinin ortaya konulduğu ve ölçme aracının geliştirildiği çalışmalar ise yüzde 4,37 ile en düşük orana sahiptir.

Tablo 5. Üstün zekâlılar ve özel yetenekliler konusunda 2010 yılından itibaren yürütülmüş tezlerin sonuçlarına göre dağılımı

\begin{tabular}{lll}
\hline Araştırmanın Sonucu & f & \% \\
\hline Etkinliklerin Üstün Zekâlı ve Özel Yetenekli Bireylerin Yaratıcılı̆̆ına Etkisi & 9 & 5,62 \\
\hline Etkinliklerin Üstün Zekâlı ve Özel Yetenekli Bireylerin Başarısına Etkisi & 12 & 7,50 \\
\hline Programların Üstün Zekâlı ve Özel Yetenekli Bireylerin Başarısına Etkisi & 11 & 6,87 \\
\hline Yöntemlerin Üstün Zekâlı ve Özel Yetenekli Bireylerin Başarısına Etkisi & 10 & 6,25 \\
\hline Yaklaşımların Üstün Zekâlı ve Özel Yetenekli Bireylerin Başarısına Etkisi & 9 & 5,62 \\
\hline Üstün Zekâlı ve Özel Yetenekli Bireyler ile Olmayanlar Arasındaki Farklar & 18 & 11,25 \\
\hline Üstün Zekâlı ve Özel Yetenekli Bireylerde Demografik Özelliklerin Etkisi & 15 & 9,37 \\
\hline Üstün Zekâlı ve Özel Yetenekli Bireylere Sahip Olan Ailelerin Eğitim İhtiyacı & 15 & 9,37 \\
\hline Üstün Zekâlı ve Özel Yetenekli Bireylere Eğitim Veren Öğretmenlerin Eğitim & 18 & 11,25 \\
İhtiyacı & 29 & 18,12 \\
\hline Üstün Zekâlı ve Özel Yetenekli Bireylerin Becerileri Arasındaki İlişki & 7 & 4,37 \\
\hline Üstün Zekâlı ve Özel Yetenekli Bireyler için Ölçme Aracı Geliştirme İhtiyacı & 7 & 4,37 \\
\hline Üstün Zekâlı ve Özel Yetenekli Bireylere Verilen Eğitimin Tarihsel Gelişimi &
\end{tabular}

\section{Tartışma ve Sonuç}

2010 y1lından itibaren üstün zekâlılar ve özel yetenekliler alanında yürütülmüş olan tezleri çeşitli değişkenler açısından incelemek ve bu konu alanında araştırma yürütmeyi planlayan araştırmacılara yol göstermek amacıyla yürütülen bu çalışmada toplam 154 tane izinli teze ulaşılmıştır.

2010 yılından itibaren üstün zekâlılar ve özel yetenekliler alanında yürütülmüş olan tezlerin yıllara ve araştırma türüne göre dağılımları incelendiğinde yükssek lisans çalışmalarına doktora çalışmalarına oranla daha fazla ağırlık verildiği olduğu görülmektedir. Yüksek lisans tezlerinin bir alanda uzmanlaşmak için, doktora tezlerinin ise evrensel bilgi birikimine katkıda bulunmak amacıyla yürütüldüğü düşünüldüğünde ülkemizde yapılan çalışmaların evrensel bilgiye katkı yapacak uluslararası literatürü etkileyecek düzeyde yoğunlaşmadığı söylenebilir. Bu bağlamda üstün zekâlılar ve özel yetenekliler konusunda doktora seviyesinde çalışmalar yapılması önerilebilir. Ayrıca araştırma kapsamında tema olarak ele alınan değişkenlerin sayısı arttırılarak 2010 yılından itibaren yerine daha geniş bir zaman aralığı seçilerek yürütülebilir.

Üstün zekâlılar ve özel yetenekliler alanında 2010 yılından itibaren yürütülmüş olan tezler konu değişkeni açısından ele alındığında 16 farklı başlık altında toplanmıştır. Yapılan incelemeler sonucunda "Üstün Zekâll ve Özel Yetenekli Bireylerin Özellikleri ve Becerileri" \% 17,53 oranla en sık rastlanan konu olarak öne çıkarken "Üstün Zekâlı ve Özel Yetenekli Bireyler ve Program- 
Model" konusu \%12,98 oranla kendisini takip etmiştir. "Üstün Zekâlı ve Özel Yetenekli Bireylerin Belirlenmesi" \% 1,94 gibi oldukça nadir bir oranda rastlanan konu olarak öne çıkarken 'Üstün Zekâlı ve Özel Yetenekli Bireyler ve Karşılaştıkları Sorunlar” \% 1,94 oranla ikinci sırayı almıştır. Ayrıca dikkat çekici bir şekilde üstün zekâlılar ve özel yeteneklilere yönelik program ve model geliştirme $(\% 12,98)$, etkinlik ve uygulama tasarlama $(\% 8,44)$ ve yeni bir yöntem ve yaklaşım oluşturma $(\% 7,14)$ konularına azımsanmayacak bir oranda değinildiği de görülmektedir. Bunların yanı sıra üstün zekâlı ve özel yetenekli bireylerin sahip olduğu becerileri geliştirmek ve yeni yeterlilikler kazandırmak adına araştırma-sorgulama anlayışı temelli çeşitli etkinlikler üzerine odaklanılması, bu yönde doktora tezleri üretilmesi ve üstün zekâlı ve özel yetenekli öğrencilerin beceri gelişimlerine odaklanılması gerekmektedir. Bu bağlamda araştırma-sorgulama sürecine odaklanılarak çalışmaların yürütülmesi ve yaratıcılık, analitik düşünce, korelasyonel düşünce gibi becerilerin kazandırılmasına yönelik örnek etkinliklerin geliştirilmesi ve test edilmesi daha faydalı olacaktır.

2010 yılından itibaren üstün zekâl1lar ve özel yetenekliler konusunda yürütülen tezlerin yaklaşımlara göre dağılımı incelendiğinde nicel, nitel ve karma olmak üzere üç farklı tema altında yaklaşımların toplanmıştır. Tezlerin 86 tanesinde (yaklaşık olarak \%55,84) nicel yaklaşımın, 40 tanesinde (yaklaşık olarak \%25,97) nitel yaklaşımın ve 28 tanesinde (yaklaşık olarak \%18,18) karma yaklaşım tercih edildiği görülmüştür. Güçin (2014) tarafından yürütülen araştırmada da üstün zekâlılar ve özel yetenekliler konusunda yürütülmüş tezlerin yaklaşımlarına göre dağılımına yönelik olarak en fazla nicel yöntemlerin tercih edildiği ortaya konulmuştur. Karma yaklaşımın, nitel ve nicel araştırma yaklaşımlarının sahip olduğu avantajların birlikte kullanıldığı dezavantajların ise diğer yaklaşım ile giderildiği tek çatı altında birleştirme işlemi (Creswell, 2003; Çepni, 2010; Leech ve Onwuegbuzie, 2009) olduğu düşünüldüğünde araştırmalardan elde edilecek verilerin zenginlik ve güvenirliği açısından daha etkili sonuçlar ve bunlara bağlı öneriler ortaya koyabileceğini ve literatüre doğrudan katk1 sağlayabileceğini söylemek pekte yanlış olmayacaktır.

Araştırmada üstün zekâlılar ve özel yetenekliler konusunda ele alınan tezler, araştırma modeline göre incelendiğinde betimsel araştırmalara teması altında bulunan survey (alan taramas1) modelinin \%31,16 oranla en fazla tercih edildiği görülmektedir. Bununla birlikte bir konu alanında derinmesine inceleme imkânı sunan ve betimsel araştırma teması altında bulunan özel durum çalışması modelinin $\% 17,53$ oranla ikinci sırada yer aldığı bulgulardan anlaşılmaktadır. Diğer bir durum ise betimsel araştırmalar teması altında bulunan gelişimci araştırma modeline de sadece bir çalışmada rastlanıyor olmasıdır. Üstün zekâlı ve özel yetenekli bireyler için geliştirilecek olan bir eğitim modelinin ya da tasarlanacak etkinliklerin bir süreç içerisinde enlemesine ya da boylamasına değerlendirilerek bireylerde ne tür değişimlere neden olacağının belirlenmesi önem arz edecektir. Dolayısıyla da üstün zekâlılar ve özel yetenekliler alanında çalışma yürütecek olan araştırmacılara, ortaya koydukları durumun evrensel düzeyde etkilerinin olacağını aşılayarak gelişimsel türden araştırmalara yönlendirilmesi önerilebilir.

Üstün zekâlılar ve özel yetenekliler konusunda 2010 yılından itibaren yayınlanmış olan tezlerin örneklem seçimine göre dağılımları incelendiğinde tezlerin 121 'inde öğrencilerin, 34 tanesinde öğretmenlerin, 19 tanesinde ebeveynlerin ve 9'unda ise idarecilerin örneklem olarak alındıkları görülmektedir. \% 66,12 oran ile en yüksek oranın öğrencilere ait olmasının altında üstün zekâlı ve özel yetenekli bireylere yönelik uygulamaların daha fazla irdelenmesi gereksiniminden 
kaynaklandığı düşünülmektedir. Eğitim-öğretim sürecinden etkilenen ve yürütülen uygulamaların ne derece anlamlı ve kalıcı olduğunun ölçülebilmesi adına bakılacak ilk kıstas genelde öğrenciler üzerindeki etkisi olmaktadır. Üstün zekâlılar ve özel yetenekliler konusunda da bireylerin gelişimine katkı sağlamak, bilim üretebilmelerini desteklemek ve yaratıcılıkları ile birlikte çeşitli ürünler ortaya koyabilmelerine yardımcı olmak (MEB, 2014) amacından da kaynaklandığ 1 düşünülmektedir. Güçin (2014) tarafından yürütülen araştırmada da üstün zekâlılar ve özel yetenekliler konusunda yürütülmüş tezlerin örneklem seçimine yönelik olarak en fazla öğrenciler üzerinde çalışmaların yürütüldüğü belirtilmiştir.

Araştırma kapsamında ele alınan tezlerin veri toplama araçlarına göre dağılımı incelendiğinde ‘ölçek, anket, envanter, test" gibi nicel veri toplama araçlarının "gözlem ve görüşme” gibi nitel veri toplama araçlarından daha fazla tercih edildiği görülmektedir. İncelenen tezlerde karma yaklaşımın tercih ediliyor olması nedeniyle nitel ve nicel veri toplama araçları bir arada kullanılmıştır. Ayrıca kullanılan ölçeklerin çoğunluğu yabancı kaynaklardan çevrilerek Türkçeye uyarlandığı belirlenmiştir. Ülkelerin sahip oldukları sosyal ve kültürel özelliklerin dinamiklere bağlı olarak değişim gösterebileceği ve farklı perspektiflere sahip olan toplumların eğitim-öğretim süreçlerinde uygulanan yaklaşımların farklılaştığı düşünüldüğünde uygulanmaya çalışan veri toplama aracında anlamlı verilerin yeterince elde edilemeyeceği varsayımını da düşünmek gerekir. Bu bağlamda çalışma hangi konuda yürütülürse yürütülsün konu alanı üzerinden temel çalışmalar yürütülüp mümkünse ölçme aracı geliştirme süreci üzerinden geçilerek araç ortaya konulmalı ve buna bağlı olarak uygulamalar yürütülmelidir. Ayrıca yurt dışında yapılandırılmış ölçme araçlarının ülkemize entegrasyonun sağlanma sürecinde sosyal , kültürel ve öğrenme alışkanlıklarımıza yönelik değişkenlerinde göz önünde bulundurulması daha etkili bir ölçme aracının geliştirilmesine vesile olacaktır.

Üstün zekâlılar ve özel yetenekliler konusunda 2010 yılından itibaren yürütülmüş tezlerin sonuçlarına göre dağılımı incelendiğinde 12 farklı tema üzerinde verilerin toplandığ belirlenmiştir. Bu temalar içerisinde en yüksek orana sahip üç sonuca bakıldığg zaman \%18,12 oran ile üstün zekâlı ve özel yetenekli bireylerin sahip oldukları beceriler arasında ilişkilerin olduğu, \%11,25 oran ile üstün zekâlı ve özel yetenekli bireyler ile olmayanlar arasında farklılaşmaların meydana geldiği ve \%11,25 oran ile üstün zekâlı ve özel yetenekli bireylere eğitim veren öğretmenlere eğitim verilmesi gerektiği ortaya konulmuştur. Gross ve van Vliet (2012) tarafindan yürütülen araştırmada da üstün zekâlı ve özel yetenekli bireylerin yaratıcılık, analitik düşünme, alg1-dikkat kontrolü, analiz-sentez gibi üst düzey düşünme becerileri arasında ilişkilerin olduğu ve bunların çeşitli etkinlik ve uygulamalar ile desteklenmesi gerektiğine vurgu yapılmıştır. Bu bağlamda karşılaştı̆ğ problemlere çözümler üretebilen, çözüm üretme sürecinde yaratıcılık ve özgünlük kıstaslarını göz önünde bulunduran ve var olan bilimsel bilgilerden yararlanarak yeni ürünler ortaya koymaya çalışan bireylerin yetiştirilmesinin önemli olduğunu vurgulamak gerekmektedir. 


\section{Türkiye'de Üstün Zekâlılar ve Özel Yetenekliler Konusunda Yürütülmüş Tezlerin Tematik}

İncelenmesine Yönelik Bir Çalıșma

\section{Kaynakça}

Altun, F. (2015). Üstün yetenekli öğrencilerin psikolojik danışma ve rehberlik ihtiyaçları, psikolojik danışma yaşantıları ve rehber öğretmenlerin üstün yeteneklilerle ilgili yeterlik düzeyleri, Yayımlanmamış Doktora Tezi, Karadeniz Teknik Üniversitesi, Trabzon.

Assouline, S. G., Blando, C., Croft, L. J., Baldus, C. \& Colangelo, N. (2009). Promoting excellence: Acceleration through enrichment. System and Models for Developing Programs for the gifted and Talented, 2, 1-16.

Așut, N. (2013). Üstün yetenekli öğrencilerin epistemolojik inançlarının fen öğrenmeye yönelik motivasyon düzeyi ve fen başarısıyla iliş̧isi, Yayımlanmamış Yüksek Lisans Tezi, İnönü Üniversitesi, Malatya.

Atalay, Z. Ö. (2014). Farklılaştırılmış sosyal bilgiler öğretiminin üstün zekâlı öğrencilerin akademik başarı, tutum, eleştirel düşünme ve yaratıcılıklarına etkisi, Yayımlanmamış Doktora Tezi, İstanbul Üniversitesi, İstanbul.

Batdal Karaduman, G. (2012). The effects of differentiated geometry teaching for fifth grade gifted students on creative thinking, spatial ability level and achievement, Yayımlanmamış Yüksek Lisans Tezi, İstanbul Üniversitesi, İstanbul.

Betts, G. T. \& Kercher J. J. (2009). The autonomous learner model for the gifted and talented, In J. S. Renzulli, E. J. Gubbins, K. S. McMillen, R. D. Erkert \& C.A. Little (Eds.), Systems and models for developing the gifted and talented ( $2^{\text {nd }}$ ed., pp. 49-105). Mansfiled Center, CT: Creative Learning Press.

Boerger, M. V. (2005). Differentiated instruction in the middle school math classroom: A case study, Unpublished Master Thesis, Pacific Lutheran University.

Camcı Erdoğan, S. ve Kahveci, N. G. (2015). Farklılaştırılmış fen ve teknoloji öğretiminin üstün zekalı ve yetenekli öğrencilerin tutumlarına etkisi, Hasan Ali Yücel Eğitim Fakültesi Dergisi, 12(1), 1-18.

Cohen, L., Manion, L., \& Morrison, K. (2000). Research methods in education (5th ed.). New York: Routledge Falmer.

Çoşkun, İ., Dündar, Ş. ve Parlak, C. (2014). Türkiye'de özel eğitim alanında yapılmış lisansüstü tezlerin çeşitli değişkenler açısından incelenmesi (2008-2013). Ege Eğitim Dergisi, 15(2), 375-396.

Cutts N.E - Moseley N. (2004). Üstün zekâlı ve üstün yetenekli çocukların eğitimi ulusun en büyük kaynaklarından birinin harcanması nasıl önlenir (Çeviren: İsmail Ersevim), İstanbul: Özgür Yayınları.

Creswell, J. W. (2003). Research design: Qualitative, quantitative, and mixed methods approaches (2nd ed.). Thousand Oaks, CA: Sage.

Çalık, M. ve Sözbilir, M. (2014). Parameters of content analysis. Egitim ve Bilim-Education and Science, 39, 33-38.

Çalıkoğlu, B. S. (2014). Üstün zekâlı ve yetenekli öğrencilerde derinlik ve karmaşıklığa göre farklılaştırılmış fen öğretiminin başarı, bilimsel süreç becerileri ve tutuma etkisi, Yayımlanmamış Doktora Tezi, İstanbul Üniversitesi, İstanbul.

Çamdeviren, Ş. (2014). Bilim ve sanat merkezine (BİLSEM) devam eden üstün yetenekli çocukların anne babalarının karşılaştıkları güçlükler (Sakarya ili örneği), Yayımlanmamış Yüksek Lisans Tezi, Sakarya Üniversitesi Eğitim Bilimleri Enstitüsü, Sakarya.

Çepni, S. (2010). Araştırma ve proje çalışmalarına giriş (5. bs.). Trabzon: Ofset Matbaacılık.

Durma, B. (2014). Üstün yetenekli ilköğretim öğrencilerinin problem çözme stratejilerini öğrenme düzeyleri, Yayımlanmamış Doktora Tezi, Uludağ Üniversitesi, Bursa. 
Dönmez, İ. ve İdin, Ş. (2017). Türkiye'de fen bilimleri eğitimi alanında üstün yetenekli öğrencilerin eğitimi ile ilgili araştırmaların incelenmesi. Üstün Zekâlılar Eğitimi ve Yaratıcılık Dergisi, 4(2), 5774.

Emir, S. (2013). Öğretmenlerin düşünme stillerinin eleştirel düşünme eğilimlerini yordama gücü (İstanbul-Fatih Örneği). Kuram ve Uygulamada Eğitim Bilimleri, 13(1), 325-347.

Gould, C. J., Weeks, V. \& Evans, S. (2003). Science starts early. Gifted Child Today Magazine, 26(3), $38-41$.

Gross, M.U.M. \& van Vliet, H.E. (2005). Radical acceleration and early entry to college: A review of research. Gifted Child Quarterly, 49(2), 154-171.

Gür, Ç. (2006). Sanat eğitim programının üst sosyo-ekonomik düzeyden gelen altı yaş üstün yetenekli çocukların çizim becerilerine etkisi, Yayımlanmamış Doktora Tezi, Gazi Üniversitesi, Ankara.

Güçin, G. (2014). Türkiye'de üstün yetenekliler ve üstün zekâlılar alanında yapılmış akademik çalışmaların çeşitli değişkenler açısından değerlendirilmesi, Yayımlanmamış Yüksek Lisans Tezi, Sosyal Bilimler Enstitüsü, Yıldız Teknik Üniversitesi, İstanbul.

Güçin, G. ve Oruç, Ş. (2015). Türkiye'de üstün yetenekliler ve üstün zekâlılar alanında yapılmış akademik çalışmaların çeşitli değişkenler açısından değerlendirilmesi. Adıyaman Üniversitesi Ĕgitim Bilimleri Dergisi, 5(2), 113-135.

Kanlı, E. (2008). Fen ve teknoloji öğretiminde probleme dayalı öğrenmenin üstün ve normal zihin düzeyindeki öğrencilerin erişi, yaratıcı düşünme ve motivasyon düzeylerine etkisi, Yayınlanmamış Yüksek Lisans Tezi, İstanbul Üniversitesi, İstanbul.

Kaplan Sayı, A. (2013). Farklılaştırılmış yabancı dil öğretiminin üstün zekâlı öğrencilerde erişiye, eleştirel düşünmeye ve yaratıcılığa etkisi, Yayımlanmamış Doktora Tezi, İstanbul Üniversitesi, İstanbul.

Karabey, B. (2010). İlköğretimdeki üstün yetenekli öğrencilerin yaratıcı problem çözmeye yönelik erişi düzeylerinin ve kritik düşünme becerilerinin belirlenmesi, Yayınlanmamış Doktora Tezi, Dokuz Eylül Üniversitesi, İzmir.

Kemaneci, G. (2012). Üstün yetenekli öğrencilerin bilim insanı hakkındaki imajlarının araştırılması, Yayımlanmamış Yüksek Lisans Tezi, Gazi Üniversitesi, Ankara.

Keser, F. F. (2012). Üstün yetenekli öğrencilerin bilim ve bilim insanına yönelik görüşlerinin ve bu görüşleri etkileyen faktörlerin belirlenmesi, Yayımlanmamış Yüksek Lisans Tezi, Gazi Üniversitesi, Ankara.

Koç, F. ve Saranlı, A. G. (2017). Erken çocukluk dönemindeki üstün yetenekli çocuklara ilişskin Türkiye'de gerçekleştirilen lisansüstü çalışmaların çok boyutlu analizi. Mehmet Akif Ersoy Üniversitesi Eğitim Fakültesi Dergisi, 41(1), 163-183.

Kök, B. (2012). Üstün zekâlı ve yetenekli öğrencilerde farklılaştırılmış geometri öğretiminin yaratıcılığa, uzamsal yeteneğe ve başarıya etkisi, Yayımlanmamış Yüksek Lisans Tezi, İstanbul Üniversitesi, İstanbul.

Leech, N. L., \& Onwuegbuzie, A. J. (2009). A typology of mixed methods research designs. Quality and Quantity, 43, 265-275.

Levent, F. (2011). Üstün yeteneklilerin eğitimine yönelik görüş ve politikaların incelenmesi, Yayımlanmamış Doktora Tezi, Marmara Üniversitesi, İstanbul.

Liu, S. Y., \& Lederman, N. G. (2002). Taiwanese gifted students' views of nature of science. School Science and Mathematics, 102(3), 114-123.

Melber, L. M (2003). Partnerships in science learning: Museum outreach and elementary gifted education. Gifted Child Quarterly, 47(4), 251-258.

Milli Eğitim Bakanlığı. (2013). T.C. Milli Eğitim Bakanlığı Özel Eğitim ve Rehberlik Hizmetleri Genel Müdürlüğü, Üstün Yetenekli Bireyler Strateji ve Uygulama Planı 2013-2017, Ankara. 


\section{Türkiye'de Üstün Zekâlılar ve Özel Yetenekliler Konusunda Yürütülmüş Tezlerin Tematik İncelenmesine Yönelik Bir Çalışma}

Milli Eğitim Bakanlığı. (2015). MEB Bilim Sanat Merkezi Yönergesi, Ankara.

National Association of Gifted Children (2006). What is Gifted? http://www.nagc.org/index. aspx?id=574 (Erişim Tarihi: 09.10.2017).

Öğretme, M. (2004). Farklılaştırılmış fizik derslerinin 9. sınıf öğrenciler üzerine etkisi. Birinci Türkiye Üstün Yetenekli Çocuklar Kongresi Seçilmiş Makaleler Kitabı, 351-356.

Özdemir. G. (2017). Üstün yetenekli öğrencilere yönelik zenginleştirilmiş öğretim programının bilimsel süreç becerilerine ve başarıya katkısına ilişkin eylem araştırması, Yayımlanmamış Yüksek Lisans Tezi, Hacettepe Üniversitesi, Ankara.

Özdemir, N. (2014). Üstün yetenekli öğrencilerin fen ve teknoloji dersine yönelik tutumlarının incelenmesi, Yayımlanmamış Yüksek Lisans Tezi, Muş Alparslan Üniversitesi, Muş.

Özenç, M. ve Özenç, E. (2013). Türkiye'de üstün yetenekli öğrencilerle ilgili yapılan lisansüstü eğitim tezlerinin çok boyutlu olarak incelenmesi. Türkiye Sosyal Araştırmalar Dergisi, 171, 13-28.

Özyaprak, M. (2012). Üstün zekâlı olan ve olmayan öğrencilerin görsel uzamsal yeteneklerinin düzeylerinin karşılaştırılması. Türk Üstün Zekâ ve Eğitim Dergisi, 2, 137-153.

Reis, S. M., \& Renzulli, J. S. (2010). Is there still a need for gifted education? An examination of current research. Learning and Individual Differences, 20, 308-317.

Schlichter, C. L. (2009). Talents unlimited: Thinking skills instruction for all students. Renzulli, J. S., Gubbins, J. E., McMillan, K. S., Eckert, R. D., \& Little, C. A. (Eds.) Systems and Models for Developing Programs for the Gifted and Talented, ( $2^{\text {nd }}$ Edition; pp. 433-455). Mansfield Center, CT: Creative Learning Press.

Schommer, M. \& Dunnell, P. A. (1997). Epistemological beliefs of gifted high school students. Roeper Review, 19(3),153-156.

Sıdar, R. (2011). Bilim sanat merkezlerinde okuyan öğrencilerin yaratıcılıklarının problem çözme becerilerine etkisi, Yayımlanmamış Yüksek Lisans Tezi, Niğde Üniversitesi, Niğde.

Sondergeld, T.A. \& Schultz R. (2008). Science, standards, and differentiation: It realy can be fun!. Gifted Child Today. 31(1), 34-40.

Springer, R. M., Pugalee, D. \& Algozzine, B. (2007). Improving mathematics skills of high school students. The Clearing House, 81(1), 37-44.

Stager, A. (2007). Differentiated instruction in mathematics, Unpublished master thesis, Caldwell College, New Jersey.

Stake, J. E. \& Mares, K, R. (2001). Science enrichment programs for gifted high school girls and boys: predictors of program impact on science confidence and motivation. Journal of Research in Science Teaching, 38(10), 1065-1088.

Sternberg, R. (2009). Düşünme Stilleri, İstanbul: Redhouse Eğitim Kitapları.

Şahin, E. (2016). Argümantasyon tabanlı bilim öğrenme yaklaşımının (ATBÖ) üstün yetenekli öğrencilerin akademik başarılarına, üstbiliş ve eleştirel düşünme becerilerine etkisi, Yayımlanmamış Doktora Tezi, Gazi Üniversitesi, Ankara.

Tebliğler Dergisi. (2001). Bilim Sanat Merkezleri Yönergesi, Sayı: 2530, Cilt: 64.

Tomlinson, C. A. (2009). Myth 8: The "patch-on" approach to programming is effective. Gifted Child Quarterly, 53, 254-256.

Tyler-Wood, T. L. (2000). An effective mathematics and science curriculum option for secondary gifted education, Roeper Review, 22(4), 266.

Ünlü, P. (2009). Üstün yetenekli öğrencilerin fizik yeteneklerinin gelişiminin ölçülmesi. Hacettepe Üniversitesi Eğitim Fakültesi Dergisi, 36, 294-305. 
Ürek, H. (2012). Üstün zekâlı olan ve olmayan ilköğretim öğrencilerinin fene ve bilime karşı algı ve tutumlarının karşılaştırılması, Yayımlanmamış Yüksek Lisans Tezi, Balıkesir Üniversitesi, Balıkesir.

VanTassel-Baska, J., Bass, G., Ries, R., Poland, D. \& Avery, L. D. (1998). A national study of science curriculum effectiveness with high ability students. Gifted Child Quarterly, 42(4), 200-211.

Van Tassel-Baska, J. \& Wood, S. M. (2009). The integrated curriculum model. J. S. Renzulli, E. J. Gubbins, K.S. McMillen, R. D. Eckert \& C. A. Little (Eds.), Systems and models for developing programs for the gifted and talented. Mansfield center, CT: Creative Learning Press.

Vural, S. (2010). Yapılandırmacı yaklaşıma uygun geliştirilen etkinliklerin üstün yetenekli öğrencilerin kavramları anlamalarına etkisi: "Erime, donma, buharlaşma, kaynama ve yoğuşma", Yayımlanmamış Yüksek Lisans Tezi, Karadeniz Teknik Üniversitesi, Trabzon.

Watters, J. J. \& Diezmann, C. M. (2003). The gifted student in science: Fulfilling potential. Australian Science Teachers Journal, 49(3), 46-54.

Wood, J. W. (2006). Teaching students in inclusive settings adapting and accommodating instruction (5 ${ }^{\text {th }}$ ed.) NJ: Pearson Education Inc.

Yılmaz Atik, Ş. (2007). İlköğretimdeki üstün yetenekli öğrencilere uygulanan öğretim yöntemlerinin değerlendirilmesi, Yayımlanmamış Yüksek Lisans Tezi. Dokuz Eylül Üniversitesi, Eğitim Bilimleri Enstitüsü, İzmir.

Yüksel, S. (2011). Fen-Edebiyat Fakültesi öğretim üyelerinin öğretmen yetiștirme sistemine ilişkin düşünceleri (Uludağ üniversitesi fen- edebiyat fakültesi örneği). Kuram ve Uygulamada Ĕgitim Bilimleri, 11(1), 179-198. 


\section{Türkiye'de Üstün Zekâlılar ve Özel Yetenekliler Konusunda Yürütülmüş Tezlerin Tematik}

İncelenmesine Yönelik Bir Çalışma

Ek-1. Üstün zekâlllar ve özel yetenekliler konusunda yürütülmüş tezlere ait genel bilgiler

\begin{tabular}{|c|c|c|c|}
\hline $\begin{array}{l}\text { Araştırmanın } \\
\text { Yılı }\end{array}$ & $\begin{array}{l}\text { Araştırmanın } \\
\text { Türü }\end{array}$ & Araştırmanın ve Araştırmacının Adı & $\begin{array}{l}\text { Araştırmanın } \\
\text { Yürütüldüğ̈̈ } \\
\text { Kurum }\end{array}$ \\
\hline 2010 & Yüksek Lisans & $\begin{array}{l}\text { İlköğretim kademesindeki üstün yetenekli ögrencilerin } \\
\text { rehberlik gereksinimlerinin ebeveynlerin ve } \\
\text { öğretmenlerin görüşlerine dayalı olarak belirlenmesi - } \\
\text { İbrahim AKAR }\end{array}$ & $\begin{array}{l}\text { Anadolu Üni. } \\
\text { Eğitim Bilimleri } \\
\text { Enstitüsü }\end{array}$ \\
\hline 2010 & Yüksek Lisans & $\begin{array}{l}\text { Orta öğretimdeki üstün yetenekli öğrencilerin duygusal } \\
\text { zekâ ve yaratıcılık düzeylerinin yaşam doyumlarını } \\
\text { yordama gücü - Eda AKKAN }\end{array}$ & $\begin{array}{l}\text { Gaziosmanpaşa } \\
\text { Üni. } \quad \text { Sosyal } \\
\text { Bilimler Enstitüsü } \\
\end{array}$ \\
\hline 2010 & Yüksek Lisans & $\begin{array}{l}\text { Üstün yetenekli öğrencilerin mükemmeliyetçilik } \\
\text { özellikleri, okul motivasyonları, öğrenme stilleri ve } \\
\text { akademik başarıları - Fatma ALTUN }\end{array}$ & $\begin{array}{l}\text { Karadeniz Teknik } \\
\text { Üni. Sosyal } \\
\text { Bilimler Enstitüsü }\end{array}$ \\
\hline 2010 & Yüksek Lisans & $\begin{array}{l}\text { Üstün yetenekli ilköğretim ikinci kademe öğrencileri için } \\
\text { matematik programına yönelik ihtiyaç analizi - Berna } \\
\text { AYGÜN }\end{array}$ & $\begin{array}{l}\text { Hacettepe Üni. } \\
\text { Sosyal Bilimler } \\
\text { Enstitüsü }\end{array}$ \\
\hline 2010 & Yüksek Lisans & $\begin{array}{l}\text { Bilim sanat merkezlerinde bilim birimlerinden destek } \\
\text { alan üstün yetenekli ögrencilerin kendi okullarında fen ve } \\
\text { teknoloji dersinde karş1laştıkları güçlüklerin } \\
\text { değerlendirilmesi - Hatice ÇELIKDELEN }\end{array}$ & $\begin{array}{l}\text { Selçuk Üni. } \\
\text { Sosyal Bilimler } \\
\text { Enstitüsü }\end{array}$ \\
\hline 2010 & Doktora & $\begin{array}{l}\text { Brigance K\&1 Screen II ile ilköğretim 1. sınıfta saptanan } \\
\text { üstün yetenekli çocuklara ve sınıf arkadaşlarına } \\
\text { uygulanan zenginleştirme programının çoklu zekâ } \\
\text { alanlarındaki performans düzeylerini arttırmaya etkisi - } \\
\text { Hatice DARGA }\end{array}$ & $\begin{array}{l}\text { Gazi Üni. Eğitim } \\
\text { Bilimleri Enstitüsü }\end{array}$ \\
\hline 2010 & Yüksek Lisans & $\begin{array}{l}\text { İlköğretim çağındaki üstün yetenekli öğrencilerle normal } \\
\text { gelişim gösteren öğrencilerin liderlik becerilerinin } \\
\text { karşılaştırılması (Kırşehir ili örneği) - Aydın GÜNEŞ }\end{array}$ & $\begin{array}{l}\text { Erciyes Üni. } \\
\text { Sosyal Bilimler } \\
\text { Enstitüsü }\end{array}$ \\
\hline 2010 & Doktora & $\begin{array}{l}\text { İlköğretimdeki üstün yetenekli öğrencilerin yaratıc1 } \\
\text { problem çözmeye yönelik erişi düzeylerinin ve kritik } \\
\text { düşünme becerilerinin belirlenmesi - Burak KARABEY }\end{array}$ & $\begin{array}{l}\text { Dokuz Eylül Üni } \\
\text { Eğitim Bilimleri } \\
\text { Enstitüsü }\end{array}$ \\
\hline 2010 & Yüksek Lisans & $\begin{array}{l}\text { Türkiye'de üstün yetenekliler eğitimi tarihi süreci - } \\
\text { Ridvan KARABULUT }\end{array}$ & $\begin{array}{l}\text { Abant İzzet } \\
\text { Baysal Üni. } \\
\text { Sosyal Bilimler } \\
\text { Enstitüsü }\end{array}$ \\
\hline 2010 & Yüksek Lisans & $\begin{array}{l}\text { Enderun Mektebi örnekleminde günümüz üstün yetenekli } \\
\text { çocukların eğitiminin değerlendirilmesi - Cihan KILIÇ }\end{array}$ & $\begin{array}{l}\text { Gazi Üni. Eğitim } \\
\text { Bilimleri Enstitüsü }\end{array}$ \\
\hline 2010 & Doktora & $\begin{array}{l}\text { Bilim ve sanat merkezine devam eden üstün yetenekli } \\
\text { çocukların ailelerine verilen bilgisayar temelli eğitimin } \\
\text { aile bireylerinin aile ilişkilerini algılamalarına ve } \\
\text { çocukların mükemmeliyetçilik düzeylerine etkisinin } \\
\text { incelenmesi - Zeynep KURTULMUŞ }\end{array}$ & $\begin{array}{l}\text { Gazi Üni. Eğitim } \\
\text { Bilimleri Enstitüsü }\end{array}$ \\
\hline 2010 & Yüksek Lisans & $\begin{array}{l}\text { Üstün yetenekli öğrencilerde yaratıcı yazma } \\
\text { çalışmalarının düzeyleri ilköğretim } 6,7,8 \text {. sınıf örneği - } \\
\text { Özge ÖZDEMIR }\end{array}$ & $\begin{array}{l}\text { Marmara Üni. } \\
\text { Eğitim Bilimleri } \\
\text { Enstitüsü }\end{array}$ \\
\hline 2010 & Yüksek Lisans & $\begin{array}{l}\text { Özel veya üstün yetenekli öğrencilere eğitim veren okul } \\
\text { ve merkezlerin incelenmesi - Şükran TANTAY }\end{array}$ & $\begin{array}{l}\text { Maltepe Üni. } \\
\text { Sosyal Bilimler } \\
\text { Enstitüsü }\end{array}$ \\
\hline 2010 & Yüksek Lisans & $\begin{array}{l}\text { Üstün yeteneklilerin eğitiminde bir model olan bilim ve } \\
\text { sanat merkezleri (BILLSEM'ler) üzerine bir araştırma - } \\
\text { Hasan YILDIZ }\end{array}$ & $\begin{array}{l}\text { Gazi Üni. Eğitim } \\
\text { Bilimleri Enstitüsü }\end{array}$ \\
\hline 2010 & Yüksek Lisans & $\begin{array}{l}\text { Yapılandırmacı yaklaşıma uygun geliştirilen etkinliklerin } \\
\text { üstün yetenekli öğrencilerin kavramları anlamalarına } \\
\text { etkisi: "Erime, donma, buharlaşma, kaynama ve } \\
\text { yoğuşma"-Selma VURAL }\end{array}$ & $\begin{array}{l}\text { Karadeniz Teknik } \\
\text { Üni. Fen } \\
\text { Bilimleri Enstitüsü }\end{array}$ \\
\hline 2011 & Yüksek Lisans & $\begin{array}{l}\text { Üstün yetenekli öğrencilerin iletkenlik ve yalıtkanlık } \\
\text { kavramları hakkındaki zihinsel modellerinin incelenmesi } \\
\text { - Mehmet ÇAKIR }\end{array}$ & $\begin{array}{l}\text { Yüzüncü Y1l Üni. } \\
\text { Fen Bilimleri } \\
\text { Enstitüsü }\end{array}$ \\
\hline 2011 & Yüksek Lisans & $\begin{array}{l}\text { Üstün yetenekli öğrencilerin çevreye yönelik bilgi ve } \\
\text { tutumlarının incelenmesi - Tarık ESEN }\end{array}$ & $\begin{array}{l}\text { Adıyaman Üni. } \\
\text { Fen Bilimleri } \\
\text { Enstitüsü }\end{array}$ \\
\hline
\end{tabular}




\begin{tabular}{|c|c|c|c|}
\hline 2011 & Yüksek Lisans & $\begin{array}{l}\text { İlköğretim ikinci kademede okuyan üstün yetenekli olan } \\
\text { ve olmayan öğrencilerin matematik kaygı düzeyleri ve } \\
\text { bunların kaynakları - Ramazan GÜREL }\end{array}$ & $\begin{array}{l}\text { Hacettepe Üni. } \\
\text { Sosyal Bilimler } \\
\text { Enstitüsü }\end{array}$ \\
\hline 2011 & Doktora & $\begin{array}{l}\text { Üstün yeteneklilerin eğitimine yönelik görüş ve } \\
\text { politikaların incelenmesi - Faruk LEVENT }\end{array}$ & $\begin{array}{l}\text { Marmara Üni. } \\
\text { Eğitim Bilimleri } \\
\text { Enstitüsü }\end{array}$ \\
\hline 2011 & Yüksek Lisans & $\begin{array}{l}\text { Üstün zekâlı öğrencilerin bakış açısıyla üstün zeka } \\
\text { etiketinin öğrencilerin çeşitli algıları üzerindeki etkileri - } \\
\text { Ercan ÖPENGIN }\end{array}$ & $\begin{array}{l}\text { Anadolu Üni. } \\
\text { Eğitim Bilimleri } \\
\text { Enstitüsü }\end{array}$ \\
\hline 2011 & Doktora & $\begin{array}{l}\text { Üstün yetenekli çocukların ailelerine yönelik geliştirilen } \\
\text { aile rehberliği programlarının etkililiğinin incelenmesi - } \\
\text { Adile Gülşah SARANLI }\end{array}$ & $\begin{array}{l}\text { Hacettepe Üni. } \\
\text { Sağlik Bilimleri } \\
\text { Enstitüsü } \\
\end{array}$ \\
\hline 2011 & Yüksek Lisans & $\begin{array}{l}\text { Üstün yetenekliler eğitim programlarına ilişkin öğretmen } \\
\text { görüşleri (BİLSEM Örneği) - Cem ŞENOL }\end{array}$ & $\begin{array}{l}\text { Fırat Üni. Eğitim } \\
\text { Bilimleri Enstitüsü }\end{array}$ \\
\hline 2011 & Yüksek Lisans & $\begin{array}{l}\text { Üstün yetenekli ve normal gelişim gösteren ilköğretim } \\
\text { öğrencilerinin empati becerileri ve duygusal zeka } \\
\text { düzeyleri ile anne-baba tutumları arasındaki ilişkinin } \\
\text { incelenmesi - Bahar UYAROĞLU }\end{array}$ & $\begin{array}{l}\text { Hacettepe Üni. } \\
\text { Sağlik Bilimleri } \\
\text { Enstitüsü }\end{array}$ \\
\hline 2012 & Yüksek Lisans & $\begin{array}{l}\text { Üstün zekâlı 6-8. sınıf öğrencilerinin iki farklı akademik } \\
\text { ortamdaki sosyometrik statülerine göre empatik } \\
\text { eğilimleri, yaşam doyumları ve aile yaşantıları - Hatice } \\
\text { AKKAN }\end{array}$ & $\begin{array}{l}\text { Dokuz Eylül Üni. } \\
\text { Eğitim Bilimleri } \\
\text { Enstitüsü }\end{array}$ \\
\hline 2012 & Doktora & $\begin{array}{l}\text { İlköğretim 5. sınıf üstün yetenekli öğrenciler için } \\
\text { farklılaştırılmış geometri ögretiminin yaratıcı düşünme, } \\
\text { uzamsal yetenek düzeyi ve erişiye etkisi - Gülşah } \\
\text { BATDAL KARADUMAN }\end{array}$ & $\begin{array}{l}\text { İstanbul Üni. } \\
\text { Sosyal Bilimler } \\
\text { Enstitüsü }\end{array}$ \\
\hline 2012 & Yüksek Lisans & $\begin{array}{l}\text { Üstün yetenekli öğrencilerin biliş ötesi farkındalık } \\
\text { düzeyleri ile öz yeterlik algılarının yaşam doyumunu } \\
\text { yordama gücü - Özkan ÇiKRIKCİ }\end{array}$ & $\begin{array}{l}\text { Karadeniz Teknik } \\
\text { Üni. Eğitim } \\
\text { Bilimleri Enstitüsü }\end{array}$ \\
\hline 2012 & Yüksek Lisans & $\begin{array}{l}\text { Üstün yetenekli öğrencilerin bilim insanı hakkındaki } \\
\text { imajlarının araştırılması - Gülfem KEMANECİ }\end{array}$ & $\begin{array}{l}\text { Gazi Üni. Eğitim } \\
\text { Bilimleri Enstitüsü }\end{array}$ \\
\hline 2012 & Yüksek Lisans & $\begin{array}{l}\text { Üstün yetenekli öğrencilerin bilim ve bilim insanına } \\
\text { yönelik görüşlerinin ve bu görüşleri etkileyen faktörlerin } \\
\text { belirlenmesi - Fatih Ferdi KESER }\end{array}$ & $\begin{array}{l}\text { Gazi Üni. Eğitim } \\
\text { Bilimleri Enstitüsü }\end{array}$ \\
\hline 2012 & Yüksek Lisans & $\begin{array}{l}\text { Bilim sanat merkezlerinde bilim etkinliklerinden } \\
\text { faydalanan üstün zekâlı ögrencilerin bilim } \\
\text { okuryazarlığının analizi - Emre KÖMEK }\end{array}$ & $\begin{array}{l}\text { Necmettin } \\
\text { Erbakan Üni. } \\
\text { Eğitim Bilimleri } \\
\text { Enstitüsü } \\
\end{array}$ \\
\hline 2012 & Yüksek Lisans & $\begin{array}{l}\text { Fen ve teknoloji öğretmenlerinin üstün yeteneklilik ve } \\
\text { üstün yeteneklilerin eğitimi ile ilgili görüşlerinin } \\
\text { incelenmesi - Kürşat KUNT }\end{array}$ & $\begin{array}{l}\text { Bülent Ecevit Üni. } \\
\text { Sosyal Bilimler } \\
\text { Enstitüsü }\end{array}$ \\
\hline 2012 & Doktora & $\begin{array}{l}\text { Liderlik becerileri geliştirme programının üstün zekalı } \\
\text { olan ve olmayan öğrencilerin liderlik becerilerine etkisi - } \\
\text { Üzeyir OGURLU }\end{array}$ & $\begin{array}{l}\text { İstanbul Üni. } \\
\text { Sosyal Bilimler } \\
\text { Enstitüsü }\end{array}$ \\
\hline 2012 & Doktora & $\begin{array}{l}\text { Üstün zekâlı ve yetenekli öğrencilere yönelik } \\
\text { farklılaştırılmış matematik öğretiminin erişi, tutum ve } \\
\text { yaratıcılığa etkisi - Melodi ÖZYAPRAK }\end{array}$ & $\begin{array}{l}\text { İstanbul Üni. } \\
\text { Sosyal Bilimler } \\
\text { Enstitüsü } \\
\end{array}$ \\
\hline 2012 & Doktora & $\begin{array}{l}\text { Sınıf öğretmenlerinin üstün yetenekli öğrenciler ve } \\
\text { özellikleri hakkında bilgi düzeylerini artırmaya yönelik } \\
\text { eğitim programının etkililiği - Feyzullah ŞAHIN }\end{array}$ & $\begin{array}{l}\text { Ankara Üni. } \\
\text { Eğitim Bilimleri } \\
\text { Enstitüsü }\end{array}$ \\
\hline 2012 & Yüksek Lisans & $\begin{array}{l}\text { Üstün zekâlı olan ve olmayan ilköğretim öğrencilerinin } \\
\text { fene ve bilime karşı alg1 ve tutumlarının karş1laştırılması } \\
\text { - Handan ÜREK }\end{array}$ & $\begin{array}{l}\text { Balıkesir Üni. Fen } \\
\text { Bilimleri Enstitüsü }\end{array}$ \\
\hline 2012 & Yüksek Lisans & $\begin{array}{l}\text { Bilim ve sanat merkezlerine devam eden } 7-11 \text { yaş üstün } \\
\text { yetenekli çocuklara verilecek sanat eğitiminin niteliği - } \\
\text { Burak YAVUZYILMAZ }\end{array}$ & $\begin{array}{l}\text { Ondokuz Mayıs } \\
\text { Üni. Eğitim }\end{array}$ \\
\hline 2012 & Doktora & $\begin{array}{l}\text { Üstün yetenekli ortaöğretim öğrencilerinin matematiksel } \\
\text { problem çözme durumlarındaki öz düzenleme } \\
\text { davranışları - Gönül YAZGAN SAĞ }\end{array}$ & $\begin{array}{l}\text { Gazi Üni. Eğitim } \\
\text { Bilimleri Enstitüsü }\end{array}$ \\
\hline 2013 & Doktora & $\begin{array}{l}\text { Üstün zekâlı çocukların ebeveynlerine yönelik } \\
\text { geliştirilen aile eğitim programının etkililiğinin } \\
\text { sınanması - Nüket AFAT }\end{array}$ & $\begin{array}{l}\text { İstanbul Üni. } \\
\text { Sosyal Bilimler } \\
\text { Enstitüsü }\end{array}$ \\
\hline
\end{tabular}


Türkiye'de Üstün Zekâlılar ve Özel Yetenekliler Konusunda Yürütülmüşs Tezlerin Tematik İncelenmesine Yönelik Bir Çalışma

\begin{tabular}{|c|c|c|c|}
\hline 2013 & Doktora & $\begin{array}{l}\text { Öğretmenler için üstün zekâlı/yetenekli öğrencilerin } \\
\text { belirlenmesi eğitim yazılımının geliştirilmesi ve } \\
\text { değerlendirilmesi- Ayşe ALKAN }\end{array}$ & $\begin{array}{l}\text { Gazi Üni. } \\
\text { Eğitim Bilimleri } \\
\text { Enstitüsü }\end{array}$ \\
\hline 2013 & Yüksek Lisans & $\begin{array}{l}\text { Üstün zekâlı ve yetenekli bireylere yönelik eğitim } \\
\text { modelleri ve öğretimsel uygulamaları - Mehmet } \\
\text { DUMAN }\end{array}$ & $\begin{array}{l}\text { Okan Üni. } \\
\text { Sosyal Bilimler } \\
\text { Enstitüsü }\end{array}$ \\
\hline 2013 & Doktora & $\begin{array}{l}\text { Fen alanında üstün yetenekli öğrencilerin tanılanmasına } \\
\text { yönelik bir model geliştirme önerisi - Feride ERCAN }\end{array}$ & $\begin{array}{l}\text { İzzet Baysal Üni. } \\
\text { Eğitim Bilimleri } \\
\text { Enstitüsü }\end{array}$ \\
\hline 2013 & Yüksek Lisans & $\begin{array}{l}\text { Bilim ve sanat merkezine devam eden üstün zekâlı ve } \\
\text { özel yetenekli çocukların sosyalleşme koşulları (Batı } \\
\text { Akdeniz Bölgesi Örneği) - Burcu ERDEM }\end{array}$ & $\begin{array}{l}\text { Süleyman Demirel } \\
\text { Üni. Sosyal } \\
\text { Bilimler Enstitüsü }\end{array}$ \\
\hline 2013 & Doktora & $\begin{array}{l}\text { Üstün yetenekli öğrencilerin görsel sanatlar eğitiminde } \\
\text { disiplinler arası öğretim etkinliklerinin değerlendirilmesi } \\
\text { (Konya BİLSEM Örneği) - Mehmet Ali GENÇ }\end{array}$ & $\begin{array}{l}\text { Selçuk Üni. } \\
\text { Eğitim Bilimleri } \\
\text { Enstitüsü }\end{array}$ \\
\hline 2013 & Yüksek Lisans & $\begin{array}{l}\text { Üstün zekâlı ve yetenekli çocukların matematik } \\
\text { tutumlarının çeşitli değişkenler açısından incelenmesi - } \\
\text { Emine HIZLI }\end{array}$ & $\begin{array}{l}\text { İstanbul Üni. } \\
\text { Sosyal Bilimler } \\
\text { Enstitüsü } \\
\end{array}$ \\
\hline 2013 & Yüksek Lisans & $\begin{array}{l}\text { Üstün yetenekli } 6,7 \text { ve } 8 \text {. sınıf öğrencilerinin çoklu zekâ } \\
\text { alanlarına göre mükemmeliyetçilik düzeylerinin } \\
\text { incelenmesi - Süleyman KAHRAMAN }\end{array}$ & $\begin{array}{l}\text { Fatih Üni. } \\
\text { Sosyal Bilimler } \\
\text { Enstitüsü }\end{array}$ \\
\hline 2013 & Doktora & $\begin{array}{l}\text { Farklılaştırılmış yabancı dil öğretiminin üstün zekâlı } \\
\text { öğrencilerde erişiye, eleştirel düşünmeye ve yaratıcılığa } \\
\text { etkisi - Aysin KAPLAN SAYI }\end{array}$ & $\begin{array}{l}\text { İstanbul Üni. } \\
\text { Sosyal Bilimler } \\
\text { Enstitüsü } \\
\end{array}$ \\
\hline 2013 & Yüksek Lisans & $\begin{array}{l}\text { Üstün yetenekli öğrencilerin epistemolojik inançlarının } \\
\text { fen öğrenmeye yönelik motivasyon düzeyi ve fen } \\
\text { başarısıyla ilişkisi - Nuriye AŞUT }\end{array}$ & $\begin{array}{l}\text { İnönü Üni. } \\
\text { Eğitim Bilimleri } \\
\text { Enstitüsü }\end{array}$ \\
\hline 2013 & Yüksek Lisans & $\begin{array}{l}\text { Üstün yetenekli öğrencilerle akranlarının çevre } \\
\text { okuryazarlığı düzeylerinin karşılaştırmalı incelenmesi - } \\
\text { Gökhan SONTAY }\end{array}$ & $\begin{array}{l}\text { Gaziosmanpaşa } \\
\text { Üni. } \\
\text { Eğitim Bilimleri } \\
\text { Enstitüsü }\end{array}$ \\
\hline 2013 & Yüksek Lisans & $\begin{array}{l}\text { Üstün yeteneklilerin psikolojik belirtileri, stres } \\
\text { kaynakları ve stres karşısındaki tepkileri - Şefika } \\
\text { SÜRÜCÜ }\end{array}$ & $\begin{array}{l}\text { Gaziosmanpaşa } \\
\text { Eğitim Bilimleri } \\
\text { Enstitüsü } \\
\end{array}$ \\
\hline 2013 & Yüksek Lisans & $\begin{array}{l}\text { Üstün yetenekli ergenlerde görülen mükemmeliyetçi } \\
\text { tutumlar ve problem çözme becerilerinin psikolojik iyilik } \\
\text { hali ile ilişkisi - Esra TOPLU }\end{array}$ & $\begin{array}{l}\text { Ankara Üni. } \\
\text { Sosyal Bilimler } \\
\text { Enstitüsü }\end{array}$ \\
\hline 2013 & Yüksek Lisans & $\begin{array}{l}\text { Üstün zekâlı olan ve olmayan öğrencilerin } \\
\text { mükemmeliyetçilik ve akademik özyeterlikleri arasındaki } \\
\text { ilişki - Dilek YILMAZ ÇELIK }\end{array}$ & $\begin{array}{l}\text { İstanbul Üni. } \\
\text { Sosyal Bilimler } \\
\text { Enstitüsü }\end{array}$ \\
\hline 2013 & Yüksek Lisans & $\begin{array}{l}\text { Sinıf öğretmenlerinin ve ilköğretim matematik } \\
\text { öğretmenlerinin matematikte üstün zekâlı öğrencilere } \\
\text { yönelik algıları - Sümeyra TÜTÜNCÜ }\end{array}$ & $\begin{array}{l}\text { ODTÜ } \\
\text { Sosyal Bilimler } \\
\text { Enstitüsü }\end{array}$ \\
\hline 2014 & Yüksek Lisans & $\begin{array}{l}\text { İlkokul 2. sınıfta okuyan üstün zekâlı bir öğrencinin } \\
\text { ikinci dil olarak İngilizce'yi öğrenmedeki motivasyonu - } \\
\text { Gamze PİŞGİN }\end{array}$ & $\begin{array}{l}\text { Bahçeşehir Üni. } \\
\text { Eğitim Bilimleri } \\
\text { Enstitüsü }\end{array}$ \\
\hline 2014 & Doktora & $\begin{array}{l}\text { Üstün yetenekli öğrencilerin matematik yaratıcılıklarını } \\
\text { açıklamaya yönelik bir model geliştirilmesi - Savaş } \\
\text { AKGÜL }\end{array}$ & $\begin{array}{l}\text { İstanbul Üni. } \\
\text { Eğitim Bilimleri } \\
\text { Enstitüsü }\end{array}$ \\
\hline 2014 & Yüksek Lisans & $\begin{array}{l}\text { Üstün zekâlı ve üstün yetenekli çocuklarda algılanan } \\
\text { sosyal destek düzeyinin benlik saygısına etkisinin } \\
\text { incelenmesi - Nurcan ALBAYRAK DENGİ }\end{array}$ & $\begin{array}{l}\text { Akdeniz Üni. } \\
\text { Eğitim Bilimleri } \\
\text { Enstitüsü }\end{array}$ \\
\hline 2014 & Doktora & $\begin{array}{l}\text { Farklılaştırılmış sosyal bilgiler öğretiminin üstün zekâlı } \\
\text { öğrencilerin akademik başarı, tutum, eleştirel düşünme } \\
\text { ve yaratıcılıklarına etkisi - Zehra Özlem ATALAY }\end{array}$ & $\begin{array}{l}\text { İstanbul Üni. } \\
\text { Eğitim Bilimleri } \\
\text { Enstitüsü }\end{array}$ \\
\hline 2014 & Doktora & $\begin{array}{l}\text { Üstün zekâlı öğrenciler için yeni bir farklılaştırma } \\
\text { yaklaşımının geliştirilmesi ve matematik ögretiminde } \\
\text { uygulanması - Esra ALTINTAŞ }\end{array}$ & $\begin{array}{l}\text { Marmara Üni. } \\
\text { Eğitim Bilimleri } \\
\text { Enstitüsü }\end{array}$ \\
\hline 2014 & Yüksek Lisans & $\begin{array}{l}\text { Üstün yetenekli 6.sınıf öğrencilerine uygulanan değerler } \\
\text { eğitimi programının etkililiği - Ersin ATEŞ }\end{array}$ & $\begin{array}{l}\text { Yeditepe Üni. } \\
\text { Eğitim Bilimleri } \\
\text { Enstitüsü }\end{array}$ \\
\hline
\end{tabular}




\begin{tabular}{|c|c|c|c|}
\hline 2014 & Yüksek Lisans & $\begin{array}{l}\text { Akademik başarısı sınıf ortalamasının altında kalan üstün } \\
\text { zekalı ortaokul ögrencilerin mükemmellik düzeyleri ile } \\
\text { algıladıkları anne-baba tutumları arasındaki ilişki - } \\
\text { Müşerref BOZKURT TİRYAKİ }\end{array}$ & $\begin{array}{l}\text { Fatih Üni. } \\
\text { Sosyal Bilimler } \\
\text { Enstitüsü }\end{array}$ \\
\hline 2014 & Doktora & $\begin{array}{l}\text { Bilimsel yaratıcılığı temel alan farklılaştırılmış fen ve } \\
\text { teknoloji öğretiminin üstün zekalı ve yetenekli } \\
\text { öğrencilerin başarı, tutum ve yaratıcıllı̆ına etkisi - Sezen } \\
\text { CAMCI ERDOĞAN }\end{array}$ & $\begin{array}{l}\text { İstanbul Üni. } \\
\text { Eğitim Bilimleri } \\
\text { Enstitüsü }\end{array}$ \\
\hline 2014 & Yüksek Lisans & $\begin{array}{l}\text { Bilim ve sanat merkezine (BÍLSEM) devam eden üstün } \\
\text { yetenekli çocukların anne babalarının karşılaştıkları } \\
\text { güçlükler (Sakarya ili örneği) - Şenel ÇAMDEVIREN }\end{array}$ & $\begin{array}{l}\text { Sakarya Üni. } \\
\text { Eğitim Bilimleri } \\
\text { Enstitüsü }\end{array}$ \\
\hline 2014 & Doktora & $\begin{array}{l}\text { Üstün yetenekli ilköğretim öğrencilerinin problem çözme } \\
\text { stratejilerini öğrenme düzeyleri - Burcu DURMAZ }\end{array}$ & $\begin{array}{l}\text { Uludağ Üni. } \\
\text { Eğitim Bilimler } \\
\text { Enstitüsü } \\
\end{array}$ \\
\hline 2014 & Yüksek Lisans & $\begin{array}{l}\text { Türkiye'de üstün yetenekliler ve üstün zekâlılar alanında } \\
\text { yapılmış akademik çalışmaların çeşitli değişkenler } \\
\text { açısından değerlendirilmesi - Gökhan GÜÇIN }\end{array}$ & $\begin{array}{l}\text { Yıldız Teknik Üni. } \\
\text { Sosyal Bilimler } \\
\text { Enstitüsü }\end{array}$ \\
\hline 2014 & Doktora & $\begin{array}{l}\text { Bireysel ve işbirlikli blogla bütünleştirilmiş yazma } \\
\text { öğretiminin normal ve üstün zekâlı öğrencilerin yazma } \\
\text { performanslarna etkisi - H. Gülhan ORHAN KARSAK }\end{array}$ & $\begin{array}{l}\text { Yıldız Teknik Üni. } \\
\text { Sosyal Bilimler } \\
\text { Enstitüsü }\end{array}$ \\
\hline 2014 & Yüksek Lisans & $\begin{array}{l}\text { Üstün yetenekli öğrencilerin sınıf içi davranış } \\
\text { sorunlarının belirlenmesi ve çözüm önerileri - Gamze } \\
\text { INCI }\end{array}$ & $\begin{array}{l}\text { Sakarya Üni. } \\
\text { Eğitim Bilimleri } \\
\text { Enstitüsü }\end{array}$ \\
\hline 2014 & Yüksek Lisans & $\begin{array}{l}\text { Üstün yetenekli çocukların sosyal medya kullanım } \\
\text { motivasyonları - İbrahim Şamil KÖROĞLU }\end{array}$ & $\begin{array}{l}\text { İstanbul Ticaret } \\
\text { Üni. } \\
\text { Sosyal Bilimler } \\
\text { Enstitüsü }\end{array}$ \\
\hline 2014 & Yüksek Lisans & $\begin{array}{l}\text { Üstün ve özel yetenekli öğrencilerin eğitiminde model } \\
\text { olan Beyazıt Ford Otosan İlköğretim Okulu üzerine bir } \\
\text { araştırma - Murat KÜÇÜKOĞLU }\end{array}$ & $\begin{array}{l}\text { Sabahattin Zaim } \\
\text { Sosyal Bilimler } \\
\text { Enstitüsü }\end{array}$ \\
\hline 2014 & Doktora & $\begin{array}{l}\text { Türkiye ve ABD’de üstün zekâlı çocuklara sosyal bilgiler } \\
\text { dersi veren öğretmenlerin görüş ve uygulamaları (HOPE } \\
\text { Projesi ve BİLSEM Örneği) - Hüseyin MERTOL }\end{array}$ & $\begin{array}{l}\text { Atatürk Üni. } \\
\text { Eğitim Bilimleri } \\
\text { Enstitüsü }\end{array}$ \\
\hline 2014 & Yüksek Lisans & $\begin{array}{l}\text { Üstün yetenekli öğrencilerin fen ve teknoloji dersine } \\
\text { yönelik tutumlarının incelenmesi - Nihat Özdemir }\end{array}$ & $\begin{array}{l}\text { Muş Alpaslan Ü. } \\
\text { Fen Bilimleri } \\
\text { Enstitüsü }\end{array}$ \\
\hline 2014 & Doktora & $\begin{array}{l}\text { Üstün yetenekli öğrencilerin kullanımı için sanal } \\
\text { gerçeklik ortamında kuvvet geribeslemeli haptik } \\
\text { uygulamaların geliştirilmesi - Hakan ÜSTÜNEL }\end{array}$ & $\begin{array}{l}\text { Trakya Üni. } \\
\text { Fen Bilimleri } \\
\text { Enstitüsü }\end{array}$ \\
\hline 2014 & Doktora & $\begin{array}{l}\text { Üstün zekalı ve yetenekli bireylerin hafiza performansına } \\
\text { EEG-biofeedback yönteminin etkisi - Mehmet Fatih } \\
\text { VARLI }\end{array}$ & $\begin{array}{l}\text { İstanbul Üni. } \\
\text { Eğitim Bilimleri } \\
\text { Enstitüsü } \\
\end{array}$ \\
\hline 2014 & Yüksek Lisans & $\begin{array}{l}\text { Üstün yetenekli beşinci sınıf öğrencilerinin öyküleyici } \\
\text { metin yazma becerileri - Ali YAYLACIK }\end{array}$ & $\begin{array}{l}\text { Mustafa Kemal } \\
\text { Üni. } \quad \text { Sosyal } \\
\text { Bilimler Enstitüsü }\end{array}$ \\
\hline 2014 & Yüksek Lisans & $\begin{array}{l}\text { Matematik alanında üstün yetenekli ve zekalı } \\
\text { ögrencilerin bazı değişkenler açısından veri madenciliği } \\
\text { ile belirlenmesi - Esra AKSOY }\end{array}$ & $\begin{array}{l}\text { Dokuz Eylül Üni } \\
\text { Eğitim Bilimleri } \\
\text { Enstitüsü }\end{array}$ \\
\hline 2014 & Doktora & $\begin{array}{l}\text { Veri madenciliği teknikleri ile üstün yetenekli } \\
\text { öğrencilerin ilgi alanlarının analizi - Özgün } \\
\text { ÇÖLLÜOĞLU GÜLEN }\end{array}$ & $\begin{array}{l}\text { Gazi Üni. Bilişim } \\
\text { Enstitüsü }\end{array}$ \\
\hline 2014 & Yüksek Lisans & $\begin{array}{l}\text { Türkiye'de üstün yetenekliler ve üstün zekâlılar alanında } \\
\text { yapılmış akademik çalışmaların çeşitli değişkenler } \\
\text { açısından değerlendirilmesi - Gökhan GÜÇiN }\end{array}$ & $\begin{array}{l}\text { Yıldız Teknik } \\
\text { Sosyal Bilimler } \\
\text { Enstitüsü } \\
\end{array}$ \\
\hline 2014 & Yüksek Lisans & $\begin{array}{l}\text { Üstün yetenekli ve normal çocukların ebeveyn kabul-red, } \\
\text { ebeveyn tutumu ve sosyal destek algıları ile yaşadıkları } \\
\text { psikolojik güçlükler arasındaki ilişkinin incelenmesi - } \\
\text { Nesibe OLGUN KAVAL }\end{array}$ & $\begin{array}{l}\text { Ege Üni. Sosyal } \\
\text { Bilimler Enstitüsü }\end{array}$ \\
\hline 2015 & Doktora & $\begin{array}{l}\text { Üstün yetenekliliği derecelendirme ölçekleri - } \\
\text { Okulöncesi/Anaokulu Formu (GRS-P)'nun Türkçeye } \\
\text { uyarlanması - Saide ALMA }\end{array}$ & $\begin{array}{l}\text { Selçuk Üni. } \\
\text { Sosyal Bilimler } \\
\text { Enstitüsü }\end{array}$ \\
\hline
\end{tabular}


Türkiye'de Üstün Zekâlılar ve Özel Yetenekliler Konusunda Yürütülmüşs Tezlerin Tematik İncelenmesine Yönelik Bir Çalışma

\begin{tabular}{|c|c|c|c|}
\hline 2015 & Doktora & $\begin{array}{l}\text { Üstün yetenekli öğrencilerin psikolojik danışma ve } \\
\text { rehberlik ihtiyaçları, psikolojik danışma yaşantıları ve } \\
\text { rehber ögretmenlerin üstün yeteneklilerle ilgili yeterlik } \\
\text { düzeyleri - Fatma ALTUN }\end{array}$ & $\begin{array}{l}\text { Karadeniz Teknik } \\
\text { Üni. } \\
\text { Eğitim Bilimleri } \\
\text { Enstitüsü }\end{array}$ \\
\hline 2015 & Yüksek Lisans & $\begin{array}{l}\text { Üstün yetenekliler eğitim programları değerlendirmeleri } \\
\text { öğrenci formunun (ÜYEP-DÖF) revize edilmesi ve } \\
\text { psikometrik özelliklerinin araştırılması -Gülşah AVCI }\end{array}$ & $\begin{array}{l}\text { Anadolu Üni. } \\
\text { Eğitim Bilimleri } \\
\text { Enstitüsü } \\
\end{array}$ \\
\hline 2015 & Yüksek Lisans & $\begin{array}{l}\text { Üstün yetenekli öğrencilerde öğrenme stilleri (Türk } \\
\text { Eğitim Vakfi İnanç Türkeş Özel Lisesi Örneği) - } \\
\text { Muharrem BAGAV }\end{array}$ & $\begin{array}{l}\text { Yeditepe Üni. } \\
\text { Eğitim Bilimleri } \\
\text { Enstitüsü }\end{array}$ \\
\hline 2015 & Yüksek Lisans & $\begin{array}{l}\text { Üstün zekâlı olan ve üstün zekalı olmayan öğrencilerin } \\
\text { benlik algısı ve ebeveynlerinin çocuk yetiştirme stilleri } \\
\text { üzerine bir yapısal eşitlik modellemesi - Bilge BAKIR }\end{array}$ & $\begin{array}{l}\text { Mersin Üni. } \\
\text { Eğitim Bilimleri } \\
\text { Enstitüsü }\end{array}$ \\
\hline 2015 & Doktora & $\begin{array}{l}\text { Müzik eğitiminin üstün zekâlı ve yetenekli öğrencilerin } \\
\text { sosyal becerilerinin gelişimine etkisi - Melek BOLAT }\end{array}$ & $\begin{array}{l}\text { Marmara Üni. } \\
\text { Eğitim Bilimleri } \\
\text { Enstitüsü }\end{array}$ \\
\hline 2015 & Yüksek Lisans & $\begin{array}{l}\text { Sekizinci sınıf üstün yetenekli öğrencilerin anomalik } \\
\text { durumlara odaklı argümantasyon (dayanaklandırma) } \\
\text { sürecinin bilimsel yaratıcılık düzeylerine etkisi - Aliye } \\
\text { Hilal CEVHER }\end{array}$ & $\begin{array}{l}\text { İnönü Üni. } \\
\text { Eğitim Bilimleri } \\
\text { Enstitüsü }\end{array}$ \\
\hline 2015 & Yüksek Lisans & $\begin{array}{l}\text { Üstün yetenekli öğrencilerin eğitiminde mentorluk ve bir } \\
\text { model önerisi - Lütfü ÇAKIR }\end{array}$ & $\begin{array}{l}\text { Yıldız Teknik Üni. } \\
\text { Sosyal Bilimler } \\
\text { Enstitüsü }\end{array}$ \\
\hline 2015 & Yüksek Lisans & $\begin{array}{l}\text { Üstün yetenekli öğrencilerin psikolojik ihtiyaçlarının } \\
\text { bazı değişkenlere göre incelenmesi - Sümeyye DOĞAN }\end{array}$ & $\begin{array}{l}\text { Necmettin } \\
\text { Erbakan Üni. } \\
\text { Eğitim Bilimleri } \\
\text { Enstitüsü }\end{array}$ \\
\hline 2015 & Doktora & $\begin{array}{l}\text { Üstün yetenekli öğrencilerin çevresinden algıladıkları } \\
\text { sosyal destek düzeyi ile sosyal duygusal becerileri } \\
\text { arasındaki ilişki - Fatih ELCİK }\end{array}$ & $\begin{array}{l}\text { Dumlupinar Üni. } \\
\text { Eğitim Bilimleri } \\
\text { Enstitüsü }\end{array}$ \\
\hline 2015 & Yüksek Lisans & $\begin{array}{l}\text { Üstün yetenekli çocukların eğitim süreçlerinde kültürel } \\
\text { ve sosyal sermaye (Ankara BİLSEM Örneği) - Sezgin } \\
\text { ERDEM }\end{array}$ & $\begin{array}{l}\text { Hacettepe Üni. } \\
\text { Sosyal Bilimler } \\
\text { Enstitüsü } \\
\end{array}$ \\
\hline 2015 & Yüksek Lisans & $\begin{array}{l}\text { Bibliyoterapi tekniğinin üstün yetenekli çocukların } \\
\text { mükemmeliyetçilik düzeylerine etkisi - Betül İLTER }\end{array}$ & $\begin{array}{l}\text { FSM Vakıf Üni. } \\
\text { Sosyal Bilimler } \\
\text { Enstitüsü }\end{array}$ \\
\hline 2015 & Yüksek Lisans & $\begin{array}{l}\text { Okul öncesi dönemde potansiyel üstün zekalı çocukların } \\
\text { belirlenmesi - Filiz KARADAĞ }\end{array}$ & $\begin{array}{l}\text { Dokuz Eylül Üni. } \\
\text { Eğitim Bilimleri } \\
\text { Enstitüsü }\end{array}$ \\
\hline 2015 & Yüksek Lisans & $\begin{array}{l}\text { Üstün yetenekli öğrencilerde sanatsal gelişim özellikleri } \\
\text { - Mustafa ÖĞÜNMEZ }\end{array}$ & $\begin{array}{l}\text { Gazi Üni. } \\
\text { Eğitim Bilimleri } \\
\text { Enstitüsü }\end{array}$ \\
\hline 2015 & Doktora & $\begin{array}{l}\text { Proje paydaşlarının bilsem biyoloji projeleri hakkındaki } \\
\text { düşünceleri ve bu projelerin üstün zekâlı ve yetenekli } \\
\text { ögrencilerin biyoloji öğrenmeye yönelik motivasyonları } \\
\text { - Murat ÖZARSLAN }\end{array}$ & $\begin{array}{l}\text { Balıkesir Üni. } \\
\text { Fen Bilimleri } \\
\text { Enstitüsü }\end{array}$ \\
\hline 2015 & Yüksek Lisans & $\begin{array}{l}\text { Yönetim bilimi açısından üstün yetenekli çocukların } \\
\text { duygusal zekâ düzeylerinin bazı değişkenler açısından } \\
\text { incelenmesi - Berrin ÖZDEN }\end{array}$ & $\begin{array}{l}\text { İstanbul Gelişim } \\
\text { Üni. Sosyal } \\
\text { Bilimler Enstitüsü }\end{array}$ \\
\hline 2015 & Yüksek Lisans & $\begin{array}{l}\text { Özel yetenekli (Üstün zekâlı ve yetenekli) ortaokul } \\
\text { öğrencilerinde yazma kaygısı - Yusuf ÖZSOY }\end{array}$ & $\begin{array}{l}\text { Sakarya Üni. } \\
\text { Eğitim Bilimleri } \\
\text { Enstitüsü }\end{array}$ \\
\hline 2015 & Yüksek Lisans & $\begin{array}{l}\text { Sınıf öğretmenlerinin üstün yetenekli öğrenciler } \\
\text { hakkındaki farkındalık düzeyleri - Volkan SÜRMELİ }\end{array}$ & $\begin{array}{l}\text { İstanbul Gelişim } \\
\text { Üni. Sosyal } \\
\text { Bilimler Enstitüsü }\end{array}$ \\
\hline 2015 & Yüksek Lisans & $\begin{array}{l}\text { Üstün yetenekli çocuklara ilişkin sınıf öğretmenlerinin } \\
\text { bilgi düzeylerinin incelenmesi - Taner ŞAYİR }\end{array}$ & $\begin{array}{l}\text { Yıldız Teknik Üni. } \\
\text { Sosyal Bilimler } \\
\text { Enstitüsü }\end{array}$ \\
\hline 2015 & Yüksek Lisans & $\begin{array}{l}\text { Enderun mektebi ile bilim ve sanat merkezlerindeki } \\
\text { üstün yetenekli öğrencilere verilen fen bilimleri } \\
\text { eğitiminin karşılaştırılması - Abdulkadir TUNCAY }\end{array}$ & $\begin{array}{l}\text { Mustafa Kemal } \\
\text { Üni. Sosyal } \\
\text { Bilimler Enstitüsü }\end{array}$ \\
\hline
\end{tabular}




\begin{tabular}{|c|c|c|c|}
\hline 2015 & Doktora & $\begin{array}{l}\text { Arkadaşlık becerilerini geliştirme programının üstün } \\
\text { zekâlı öğrencilerin arkadaşlık ilişkilerine etkisi - } \\
\text { Hümeyra UYSALER }\end{array}$ & $\begin{array}{l}\text { İstanbul Üni. } \\
\text { Eğitim Bilimleri } \\
\text { Enstitüsü } \\
\end{array}$ \\
\hline 2015 & Yüksek Lisans & $\begin{array}{l}\text { Üstün Zekâlı Ergenlerin Akran İlişkileri ile Öznel İyi } \\
\text { Oluşları Arasındaki İlişkinin İncelenmesi - Fatma EROL }\end{array}$ & $\begin{array}{l}\text { Marmara Üni. } \\
\text { Eğitim Bilimleri }\end{array}$ \\
\hline 2015 & Yüksek Lisans & $\begin{array}{l}\text { Okul öncesi öğretmenlerinin üstün yetenekli çocuklara } \\
\text { yönelik algıları ile tutumları arasındaki ilişkinin } \\
\text { incelenmesi - Bayram SEYHAN }\end{array}$ & $\begin{array}{l}\text { Gazi Üni. Eğitim } \\
\text { Bilimleri Enstitüsü }\end{array}$ \\
\hline 2015 & Yüksek Lisans & $\begin{array}{l}\text { Müzik eğitiminin üstün zekâlı ve yetenekli öğrencilerin } \\
\text { sosyal becerilerinin gelişimine etkisi - Melike BOLAT }\end{array}$ & $\begin{array}{l}\text { Marmara Üni. } \\
\text { Eğitim Bilimleri } \\
\text { Enstitüsü }\end{array}$ \\
\hline 2015 & Yüksek Lisans & $\begin{array}{l}\text { Üstün yetenekli öğrencilerin (ilkokul 3. ve 4. sınıf } \\
\text { düzeyinde) (BİLSEM'lere) seçim sürecine ilişkin } \\
\text { yönetici ve öğretmen görüşleri açısından incelenmesi } \\
\text { (Kocaeli ili İzmit ilçesi örneği) - Emine ŞAHIN }\end{array}$ & $\begin{array}{l}\text { Okan Üni. Sosyal } \\
\text { Bilimler Enstitüsü }\end{array}$ \\
\hline 2015 & Doktora & $\begin{array}{l}\text { Fen ve matematik entegrasyonu ile hazırlanan } \\
\text { etkinliklerin üstün yetenekli ortaokul } 6 \text {. sınıf } \\
\text { öğrencilerinin eleştirel düşünme ve bilimsel süreç } \\
\text { becerilerine etkisi - Ahsen Seda KILIÇ }\end{array}$ & $\begin{array}{l}\text { Gazi Üni. Eğitim } \\
\text { Bilimleri Enstitüsü }\end{array}$ \\
\hline 2016 & Yüksek Lisans & $\begin{array}{l}\text { Üstün zekâlı ve yetenekli ergenlerin benlik saygıları, } \\
\text { depresyon düzeyleri ve fonksiyonel olmayan } \\
\text { tutumlarının değerlendirilmesi - Ece TOÇOĞLU }\end{array}$ & $\begin{array}{l}\text { Üsküdar Üni. } \\
\text { Sosyal Bilimler } \\
\text { Enstitüsü }\end{array}$ \\
\hline 2016 & Yüksek Lisans & $\begin{array}{l}\text { Fen bilimleri dersinde probleme dayalı öğrenme yöntemi } \\
\text { kullanımının üstün yetenekli öğrencilerin akademik } \\
\text { başarıları, sorgulayıcı öğrenme beceri algıları ve fene } \\
\text { yönelik tutumları üzerindeki etkileri - Sıla BALIM }\end{array}$ & $\begin{array}{l}\text { Dokuz Eylül Üni. } \\
\text { Eğitim Bilimleri } \\
\text { Enstitüsü }\end{array}$ \\
\hline 2016 & Yüksek Lisans & $\begin{array}{l}\text { Erken çocuklukta üstün yetenekli ve normal gelişim } \\
\text { gösteren çocukların ahlaki akıl yürütmelerinin } \\
\text { incelenmesi - Şifa Kevser ÇAKMAK TELOĞLU }\end{array}$ & $\begin{array}{l}\text { Hacettepe Üni. } \\
\text { Eğitim Bilimleri } \\
\text { Enstitüsü }\end{array}$ \\
\hline 2016 & Doktora & $\begin{array}{l}\text { Ebeveynin üstün yetenekli çocuğuyla iletişimini } \\
\text { geliştirmeye yönelik psikoeğitim programının etkisinin } \\
\text { incelenmesi - Süleyman KAHRAMAN }\end{array}$ & $\begin{array}{l}\text { İstanbul Üni. } \\
\text { Eğitim Bilimleri } \\
\text { Enstitüsü }\end{array}$ \\
\hline 2016 & Doktora & $\begin{array}{l}\text { Üstün yetenekli öğrencilere yazılım geliştirme } \\
\text { süreçlerinin öğretilmesine yönelik bir öğretim } \\
\text { programının tasarlanması ve geliştirilmesi - Hatice } \\
\text { DURAK }\end{array}$ & $\begin{array}{l}\text { Gazi Üni. Eğitim } \\
\text { Bilimleri Enstitüsü }\end{array}$ \\
\hline 2016 & Yüksek Lisans & $\begin{array}{l}\text { Üstün yetenekli öğrencilerle akranlarının çevreye yönelik } \\
\text { tutumlarının ve çevre sorunlarına çözüm önerilerinin } \\
\text { karşılaştırmalı incelenmesi - Şahin ÇAYIR }\end{array}$ & $\begin{array}{l}\text { Sakarya Üni. } \\
\text { Eğitim Bilimleri } \\
\text { Enstitüsü }\end{array}$ \\
\hline 2016 & Doktora & $\begin{array}{l}\text { Ortak bilgi yapılandırma modeline uygun geliştirilen } \\
\text { ögretim materyalinin üstün yetenekli öğrencilerin asit- } \\
\text { baz kavramlarını anlamaları üzerine etkisi - Selma } \\
\text { VURAL }\end{array}$ & $\begin{array}{l}\text { Karadeniz Teknik } \\
\text { Üni. Eğitim } \\
\text { Bilimleri Enstitüsü }\end{array}$ \\
\hline 2016 & Doktora & $\begin{array}{l}\text { Beşinci ve altıncı sınıf matematikte üstün yetenekli } \\
\text { ögrencilere yönelik farklılaştırılmış etkinliklerin } \\
\text { tasarlanması ve geliştirilmesi - Duygu ÖZDEMIR }\end{array}$ & $\begin{array}{lr}\text { ODTÜ Sosyal } \\
\text { Bilimler Enstitüsü }\end{array}$ \\
\hline 2016 & Doktora & $\begin{array}{l}\text { Üstün yetenekli tanısı konulmuş ve konulmamış } \\
\text { öğrencilerin matematikte yaratıcılıklarının incelenmesi: } \\
\text { Bir özel durum çalışması - Duygu TAŞKIN }\end{array}$ & $\begin{array}{l}\text { Karadeniz Teknik } \\
\text { Üni. Eğitim } \\
\text { Bilimleri Enstitüsü }\end{array}$ \\
\hline 2016 & Doktora & $\begin{array}{l}\text { Üstün yetenekli öğrencilerin öğretmenlerine yönelik } \\
\text { seçim teorisi temelli öğretmen eğitim programının } \\
\text { etkililiği - Nisa GÖKDEN KAYA }\end{array}$ & $\begin{array}{l}\text { Gazi Üni. Eğitim } \\
\text { Bilimleri Enstitüsü }\end{array}$ \\
\hline 2016 & Yüksek Lisans & $\begin{array}{l}\text { Üstün yetenekli öğrencilerin bilişim teknolojilerinden } \\
\text { yararlanma düzeyleri - Mehmet AYDIN }\end{array}$ & $\begin{array}{l}\text { Ahi Evran Üni. } \\
\text { Sosyal Bilimler } \\
\text { Enstitüsü }\end{array}$ \\
\hline 2016 & Doktora & $\begin{array}{l}\text { Proje temelli yaklaşıma dayalı erken müdahale } \\
\text { programının üstün yetenekli çocukların problem çözme } \\
\text { becerisine etkisi - Ahmet BÍLDİREN }\end{array}$ & $\begin{array}{l}\text { Ankara Üni. } \\
\text { Eğitim Bilimleri } \\
\text { Enstitüsü }\end{array}$ \\
\hline 2016 & Doktora & $\begin{array}{l}\text { Sorgulamaya dayalı öğrenmenin üstün zekâlı ve } \\
\text { yetenekli öğrencilerin asitler-bazlar konusunu } \\
\text { anlamalarına ve fen öğrenimine yönelik } \\
\text { motivasyonlarına etkisi - Sinem DINÇOL ÖZGÜR }\end{array}$ & $\begin{array}{l}\text { Hacettepe Üni. } \\
\text { Eğitim Bilimleri } \\
\text { Enstitüsü }\end{array}$ \\
\hline
\end{tabular}




\section{Türkiye'de Üstün Zekâlılar ve Özel Yetenekliler Konusunda Yürüttülmüş Tezlerin Tematik}

İncelenmesine Yönelik Bir Çalışma

\begin{tabular}{|c|c|c|c|}
\hline 2016 & Doktora & $\begin{array}{l}\text { Rol model içerikli animasyonların üstün yetenekli 4. sınıf } \\
\text { ögrencilerinin fen bilimleri dersinde zihinsel risk alma } \\
\text { davranışları ve öğrenmelerine etkisi - Gamze AKKAYA }\end{array}$ & $\begin{array}{l}\text { İnönü Üni. } \\
\text { Eğitim Bilimleri } \\
\text { Enstitüsü }\end{array}$ \\
\hline 2016 & Yüksek Lisans & $\begin{array}{l}\text { Üstün yetenekli öğrencilerin ihtiyaçlarına yönelik } \\
\text { bilgisayar alanı destek eğitim etkinliklerinin } \\
\text { tasarlanması, uygulanması ve değerlendirilmesi - Dilara } \\
\text { Arzugül AKSOY }\end{array}$ & $\begin{array}{l}\text { Karadeniz Teknik } \\
\text { Üni. Eğitim } \\
\text { Bilimleri Enstitüsü }\end{array}$ \\
\hline 2016 & Yüksek Lisans & $\begin{array}{l}\text { Okul öncesi öğretmenlerinin öz-yeterlik düzeyleri ile } \\
\text { üstün yeteneklilerin eğitimine yönelik tutumlarının } \\
\text { karş1laştırılması - Şabanağa DAŞTAN }\end{array}$ & $\begin{array}{l}\text { Gazi Üni. Eğitim } \\
\text { Bilimleri Enstitüsü }\end{array}$ \\
\hline 2016 & Yüksek Lisans & $\begin{array}{l}\text { Üstün zekâlı öğrenciler ve eğitimlerine yönelik tutum } \\
\text { ölçeği - Recep ERDOĞAN }\end{array}$ & $\begin{array}{l}\text { Gaziosmanpaşa } \\
\text { Üni. Eğitim } \\
\text { Bilimleri Enstitüsü }\end{array}$ \\
\hline 2016 & Yüksek Lisans & $\begin{array}{l}\text { Üstün zekâlı çocukların duygusal zekâya ilişkin gelişim } \\
\text { süreçlerinde iletişimin rolü - Naif KARA }\end{array}$ & $\begin{array}{l}\text { Kocaeli Üni. } \\
\text { Sosyal Bilimler } \\
\text { Enstitüsü }\end{array}$ \\
\hline 2016 & Doktora & $\begin{array}{l}\text { Üstün yetenek potansiyeli olan çocuklara uygulanan } \\
\text { sosyal beceri eğitim programının sosyal beceri gelişimine } \\
\text { etkisinin incelenmesi - Başak KARATEKE }\end{array}$ & $\begin{array}{l}\text { Gazi Üni. } \\
\text { Eğitim Bilimleri } \\
\text { Enstitüsü }\end{array}$ \\
\hline 2016 & Yüksek Lisans & $\begin{array}{l}\text { Üstün yetenekli öğrencilerin bilsem ve matematik } \\
\text { kavramına ait metaforik algılarının incelenmesi - İsmail } \\
\text { SATMAZ }\end{array}$ & $\begin{array}{l}\text { Onsekiz Mart Üni. } \\
\text { Eğitim Bilimleri } \\
\text { Enstitüsü }\end{array}$ \\
\hline 2016 & Doktora & $\begin{array}{l}\text { Argümantasyon tabanlı bilim öğrenme yaklaşımının } \\
\text { (ATBÖ) üstün yetenekli öğrencilerin akademik } \\
\text { başarılarına, üstbiliş ve eleştirel düşünme becerilerine } \\
\text { etkisi - Erhan ŞAHIN }\end{array}$ & $\begin{array}{l}\text { Gazi Üni. } \\
\text { Eğitim Bilimleri } \\
\text { Enstitüsü }\end{array}$ \\
\hline 2016 & Yüksek Lisans & $\begin{array}{l}\text { Özel eğitim gruplamasının üstün yetenekli öğrencilerin } \\
\text { akademik benlik algıları üzerindeki etkisi - Fatih } \\
\text { TOKMAK }\end{array}$ & $\begin{array}{l}\text { Anadolu Üni. } \\
\text { Eğitim Bilimleri } \\
\text { Enstitüsü }\end{array}$ \\
\hline 2016 & Yüksek Lisans & $\begin{array}{l}\text { Üstün yetenekli öğrencilerin duygusal zekâ ile karar } \\
\text { verme stratejileri arasındaki ilişkinin belirlenmesi - } \\
\text { Leyla ZAROĞLU }\end{array}$ & $\begin{array}{l}\text { Yakın Doğu Üni } \\
\text { Eğitim Bilimleri } \\
\text { Enstitüsü }\end{array}$ \\
\hline 2016 & Doktora & $\begin{array}{l}\text { Üstün yetenekli öğrencilere sunulan olumlu davranışsal } \\
\text { destek temelli problem davranışları önleyici sınıf } \\
\text { yönetimi uygulamaları: Eylem araştırması - Mahmut } \\
\text { ÇİTíL }\end{array}$ & $\begin{array}{l}\text { Gazi Üni. } \\
\text { Eğitim Bilimleri } \\
\text { Enstitüsü }\end{array}$ \\
\hline 2016 & Yüksek Lisans & $\begin{array}{l}\text { Okul öncesi öğretmenlerinin, üstün yetenekli çocuklar } \\
\text { hakkındaki alg1, görüş ve eğitim ihtiyaçlarının } \\
\text { belirlenmesi - Şener GÜLKAYA }\end{array}$ & $\begin{array}{l}\text { Yakın Doğu Üni } \\
\text { Yurtdış1 Enstitüsü }\end{array}$ \\
\hline 2016 & Yüksek Lisans & $\begin{array}{l}\text { Üstün yetenekli/zekalı çocuklarda somut ve soyut } \\
\text { anlamsal ulamların Türkçe ve İngilizce öntürleri - Fatma } \\
\text { CAN AGAOĞLU }\end{array}$ & $\begin{array}{l}\text { Ankara Üni. } \\
\text { Sosyal Bilimler } \\
\text { Enstitüsü } \\
\end{array}$ \\
\hline 2016 & Yüksek Lisans & $\begin{array}{l}\text { İlkokula devam eden üstün yetenekli çocukların sosyal } \\
\text { davranış özellikleri ile benlik algıları arasındaki ilişkinin } \\
\text { incelenmesi (Bahçelievler ilçesi örneği) - Şeyma } \\
\text { ARSLAN }\end{array}$ & $\begin{array}{l}\text { Marmara Üni. } \\
\text { Eğitim Bilimleri } \\
\text { Enstitüsü }\end{array}$ \\
\hline 2017 & Yüksek Lisans & $\begin{array}{l}\text { Türkiye Cumhuriyeti Devletinin özel yetenekliler eğitim } \\
\text { politikasının BİLSEM müdürleri ve ilgili öğretim } \\
\text { üyelerinin bakış açılarıyla değerlendirilmesi - Şevket } \\
\text { Başer KEMAHLI }\end{array}$ & $\begin{array}{l}\text { Marmara Üni. } \\
\text { Eğitim Bilimleri } \\
\text { Enstitüsü }\end{array}$ \\
\hline 2017 & Yüksek Lisans & $\begin{array}{l}\text { Üstün/özel yetenekli öğrencilerin geometri düzeylerinin } \\
\text { bazı değişkenler açısından belirlenmesi - Tuğçe Merve } \\
\text { SAĞIR }\end{array}$ & $\begin{array}{l}\text { Dokuz Eylül Üni } \\
\text { Eğitim Bilimleri } \\
\text { Enstitüsü }\end{array}$ \\
\hline 2017 & Yüksek Lisans & $\begin{array}{l}\text { Üstün / özel yetenekli öğrencilere yönelik destek eğitim } \\
\text { odası uygulaması: Sınıf öğretmenlerinin öz yeterlikleri } \\
\text { ve görüşleri - Batuhan NAR }\end{array}$ & $\begin{array}{l}\text { İstanbul Aydın } \\
\text { Sosyal Bilimler } \\
\text { Enstitüsü }\end{array}$ \\
\hline 2017 & Yüksek Lisans & $\begin{array}{l}\text { Özel yetenekli öğrencilerin bilgisayara yönelik tutumları } \\
\text { ve teknoloji ile kendi kendine öğrenmeleri arasındaki } \\
\text { ilişkinin incelenmesi - Levent TAŞDEMIR }\end{array}$ & $\begin{array}{l}\text { Gazi Üni. Eğitim } \\
\text { Bilimleri Enstitüsü }\end{array}$ \\
\hline 2017 & Yüksek Lisans & $\begin{array}{l}\text { Üstün/özel yetenekli öğrenciler için okul dişı STEM } \\
\text { eğitiminin değerlendirilmesi - Aybike ÖZÇELIK }\end{array}$ & $\begin{array}{l}\text { İstanbul Aydın } \\
\text { Sosyal Bilimler } \\
\text { Enstitüsü }\end{array}$ \\
\hline
\end{tabular}




\begin{tabular}{|c|c|c|c|}
\hline 2017 & Yüksek Lisans & $\begin{array}{l}\text { Üstün yetenekli ilköğretim öğrencilerine yönelik } \\
\text { manyetizma odaklı bir öğretim materyali (model) } \\
\text { geliştirme - Simge KARAKAŞ }\end{array}$ & $\begin{array}{l}\text { İnönü Üni. Eğitim } \\
\text { Bilimleri Enstitüsü }\end{array}$ \\
\hline 2017 & Yüksek Lisans & $\begin{array}{l}\text { Ortaokul öğrencileri ile aynı düzeydeki üstün yetenekli } \\
\text { öğrencilerin fen bilimleri özyeterliklerinin } \\
\text { karşılaştırılması - Kübra Şengül YILDIRIM }\end{array}$ & $\begin{array}{l}\text { Erciyes Üni. } \\
\text { Eğitim Bilimleri } \\
\text { Enstitüsü }\end{array}$ \\
\hline 2017 & Doktora & $\begin{array}{l}\text { Üstün yetenekli ögrencilere yönelik geliştirilen } \\
\text { farklılaştırılmış matematik dersi öğretim programının } \\
\text { etkililiği - Tünay ÖZÇELIK }\end{array}$ & $\begin{array}{l}\text { Hacettepe Üni. } \\
\text { Eğitim Bilimleri } \\
\text { Enstitüsü }\end{array}$ \\
\hline 2017 & Yüksek Lisans & $\begin{array}{l}\text { Üstün yetenekli } 7 \text { ve } 8 \text {. sınıf öğrencilerin akademik } \\
\text { başarılarına etki eden faktörler - Saniye MECEK }\end{array}$ & $\begin{array}{l}\text { Mehmet Akif } \\
\text { Ersoy Üni. Eğitim } \\
\text { Bilimleri Enstitüsü }\end{array}$ \\
\hline 2017 & Doktora & $\begin{array}{l}\text { Bir fen öğretmeninin pedagojik alan bilgisinin konuya } \\
\text { özgü doğasının incelenmesi; üstün yetenekli öğrencilerin } \\
\text { ögretmeninin durumu - Burak ÇAYLAK }\end{array}$ & $\begin{array}{lr}\text { ODTÜ } & \text { Sosyal } \\
\text { Bilimler Enstitüsü }\end{array}$ \\
\hline 2017 & Yüksek Lisans & $\begin{array}{l}\text { Üstün yetenekli çocukların anneleriyle olan ilişkileri ve } \\
\text { başarı güdüleri - Kübra ARSLAN }\end{array}$ & $\begin{array}{l}\text { Çukurova Üni. } \\
\text { Sosyal Bilimler }\end{array}$ \\
\hline 2017 & Yüksek Lisans & $\begin{array}{l}\text { Üstün yetenekli çocuklara sahip ailelerin aile işlevselliği } \\
\text { - Merve ÇALIŞKAN }\end{array}$ & $\begin{array}{l}\text { Hasan Kalyoncu } \\
\text { Üni. Sosyal } \\
\text { Bilimler Enstitüsü }\end{array}$ \\
\hline 2017 & Yüksek Lisans & $\begin{array}{l}\text { Üstün yetenekli öğrencilerde yaratıcı biliş ve özerk } \\
\text { öğrenme becerileri arasındaki ilişkinin incelenmesi - } \\
\text { Kübra ÇELIKK }\end{array}$ & $\begin{array}{l}\text { Sakarya Üni. } \\
\text { Eğitim Bilimleri } \\
\text { Enstitüsü }\end{array}$ \\
\hline 2017 & Yüksek Lisans & $\begin{array}{l}\text { Üstün yetenekli çocuklara sahip ailelerin danışmanlık } \\
\text { ihtiyaçlarının saptanması - Şule IHLAMUR }\end{array}$ & $\begin{array}{l}\text { İstanbul Ticaret } \\
\text { Üni. Sosyal } \\
\text { Bilimler Enstitüsü }\end{array}$ \\
\hline 2017 & Yüksek Lisans & $\begin{array}{l}\text { Bilim ve sanat merkezi'nde eğitim alan } 6 \text {. ve } 7 \text {. sınıf } \\
\text { ögrencileri ve velilerinin üstün/özel yetenek, zekâ ve } \\
\text { akademik başarı kavramlarıyla ilgili metaforları - Seyit } \\
\text { KARABURÇAK }\end{array}$ & $\begin{array}{l}\text { Kirıkkale Üni. } \\
\text { Sosyal Bilimler } \\
\text { Enstitüsü }\end{array}$ \\
\hline 2017 & Yüksek Lisans & $\begin{array}{l}\text { Özel yetenekli olan ve olmayan } 4 \text {. ve } 5 \text {. sınıf } \\
\text { öğrencilerinin liderlik becerilerinin empati becerileri ile } \\
\text { ilişkisinin incelenmesi - Hatice Derya KÜÇÜK }\end{array}$ & $\begin{array}{l}\text { Bahçeşehir Üni. } \\
\text { Eğitim Bilimleri } \\
\text { Enstitüsü }\end{array}$ \\
\hline 2017 & Yüksek Lisans & $\begin{array}{l}\text { Üstün yetenekli öğrencilere yönelik zenginleştirilmiş } \\
\text { öğretim programının bilimsel süreç becerilerine ve } \\
\text { başarıya katkısına ilişkin eylem araştırması - Gizem } \\
\text { ÖZDEMIR }\end{array}$ & $\begin{array}{l}\text { Hacettepe Üni. } \\
\text { Eğitim Bilimleri } \\
\text { Enstitüsü }\end{array}$ \\
\hline 2017 & Doktora & $\begin{array}{l}\text { Üstün yetenekli öğrencilerin matematiksel } \\
\text { yaratıcilıklarının matematiksel modelleme etkinlikleri } \\
\text { süreciyle incelenmesi - Şeyma ŞENGILL AKAR }\end{array}$ & $\begin{array}{l}\text { Hacettepe Üni. } \\
\text { Eğitim Bilimleri } \\
\text { Enstitüsü }\end{array}$ \\
\hline 2017 & Doktora & $\begin{array}{l}\text { Kimyasal değişim temalı farklılaştırılmış etkinliklerin } 7 . \\
\text { sınıf özel yetenekli öğrencilerin kavramsal anlamalarına } \\
\text { ve farkındalıklarına etkisi - Handan ÜREK }\end{array}$ & $\begin{array}{l}\text { Balıkesir Üni. Fen } \\
\text { Bilimleri Enstitüsü }\end{array}$ \\
\hline 2017 & Doktora & $\begin{array}{l}\text { İlköğretim düzeyindeki üstün yetenekli öğrencilerin } \\
\text { çeşitli sosyobilimsel konulara ilişkin argümantasyon } \\
\text { kalitesinin ve informal düşünme becerisinin incelenmesi } \\
\text { - Melike AKBAŞ }\end{array}$ & $\begin{array}{l}\text { Abant İzzet } \\
\text { Baysal Üni. } \\
\text { Eğitim Bilimleri } \\
\text { Enstitüsü }\end{array}$ \\
\hline 2017 & Yüksek Lisans & $\begin{array}{l}\text { Üstün yetenekli öğrencilerin eğitiminde bütünleştirilmiş } \\
\text { müfredat modeline göre farklılaştırılmış sosyal bilgiler } \\
\text { öğretimi - Şengül KORKUT }\end{array}$ & $\begin{array}{l}\text { İnönü Üni. Eğitim } \\
\text { Bilimleri Enstitüsü }\end{array}$ \\
\hline 2017 & Yüksek Lisans & $\begin{array}{l}\text { İlkokul çağındaki üstün yetenekli öğrencilerin istendik } \\
\text { özelliklerinin öğretim ortamına yansımaları - Seda } \\
\text { ARSLAN }\end{array}$ & $\begin{array}{l}\text { Amasya Üni. } \\
\text { Sosyal Bilimler } \\
\text { Enstitüsü }\end{array}$ \\
\hline 2017 & Yüksek Lisans & $\begin{array}{l}\text { Üstün yetenekli öğrencilerin yaratıcılığını geliştirmeye } \\
\text { yönelik programın etkililiği - Özden BÜTÜN }\end{array}$ & $\begin{array}{l}\text { İstanbul Üni. } \\
\text { Eğitim Bilimleri } \\
\text { Enstitüsü }\end{array}$ \\
\hline 2017 & Yüksek Lisans & $\begin{array}{l}\text { Üstün yetenekli ve normal öğrencilerin matematiksel } \\
\text { örüntü başarılarının incelenmesi - Şükran DAYAN }\end{array}$ & $\begin{array}{l}\text { Abant İzzet } \\
\text { Baysal Üni. } \\
\text { Eğitim Bilimleri } \\
\text { Enstitüsü }\end{array}$ \\
\hline
\end{tabular}




\section{Extended Abstract}

\section{Introduction}

The societies that want to use the science-product-matter cycle in a meaningful and correct way are in an effort to raise individuals who are trying to introduce new products by using scientific information, to present solution to the problems they encounter, to present scientific creativity and originality criteria in the process of solution, in accordance with the cognitive, emotional and psychomotor equipment possessed by the individual (Levent, 2011), In this context, the individuals who guide societies from the past to the present day, is not the "passive majority" of the society; they are gifted and talented students called "active minorities" who have competencies such as leadership, productivity, productivity, more advanced understanding, comprehension and observation from their peers, the development of these individuals' abilities giving opportunities and using their capacities at the highest level is of great importance for the present and future of the countries (Cutts-Moseley, 2004). Studies have been carried out in terms of various variables for gifted and talented students who are such an important structure for the societies, have gained the discipline of scientific work, are capable of interdisciplinary thinking, able to solve daily life problems or meet the specified needs. However, studies about in-depth investigation and examination in terms of various variables on gifted and talented individuals have not been found. In this context, it is aimed to investigate the studies conducted in the field of gifted and talented individuals in terms of various variables from 2010 and to guide the researchers planning to carry out research in this field.

\section{Methodology}

Document analysis method was used the research based on qualitative approach. This method seems to be appropriate since the aim of this study is to investigate the studies carried out in the field of gifted and talented individuals from 2010 in terms of various variables and lead the researcher planning to carry out research in this field. The study was done by investigating the theses in the Thesis Center of Council of Higher Education found by using the keywords which are "Gifted" and "Talented".

The first theme is indication of the distribution of gifted and talented individuals according to years and types of theses which has been conducted since 2010. It was determined that $68,83 \%$ of the theses are master degree and $31,17 \%$ of the theses are doctorate between 2010 and 2017. The second theme is indication of the distribution of gifted and talented individuals according to subjects of theses which has been conducted since 2010. Theses on gifted and talented individuals are analyzed, studies about their characteristics and skills are higher percentage than other studies and studies about process of identifying individuals are lower percentage than other studies. The third theme is indication of the distribution of gifted and talented individuals according to years and approach of theses which has been conducted since 2010. It was determined that approximately 55,84\% $(\mathrm{n}=86)$ of the theses are quantitavie research, 25,97\% $(n=40)$ of the theses are qualitative research and $18,18 \%(n=28)$ of the theses are mixed method research between 2010 and 2017. The fourth theme is indication of the distribution of gifted and talented individuals according to method and model of theses which has been conducted since 2010. Research of theses on gifted and talented individuals have been examined through 4 themes including descriptive research, interpretative research, analytical research and experimental research. The fifth theme is indication of the distribution of gifted 
and talented individuals according to sample selection of theses which has been conducted since 2010. Sample selection of theses on gifted and talented individuals have been examined through 4 themes including student, parent, teacher and manager. The sixth theme is indication of the distribution of gifted and talented individuals according to data collection tools of theses which has been conducted since 2010. Data collection tools of theses on gifted and talented individuals have been determined qualitative and quantitative which has been conducted since 2010. The seventh theme is indication of the distribution of gifted and talented individuals according to conclusions of theses which has been conducted since 2010. Studies which have been revealed relationship between skills of gifted and talented individuals have the highest level with $18.12 \%$ percent. Studies which are historical development of education given to gifted and talented individuals have the lowest level with $4.37 \%$ percent.

\section{Discussion}

The purpose of master degree theses meant to specialize in a field and the purpose of doctorate theses contribute to the accumulation of universal knowledge. Hence, it can be said that studies which are conducted in our country can't effect to international literature which are contribute the accumulation of universal knowledge. In this context, it should be conducted in doctorate theses which on gifted and talented individuals. By the way, it should be increased the number of themes or selected the more time range for conduct studies. Theses on gifted and talented individuals according to distribution of research model; survey research method which is in the descriptive research is the most preferred $31.16 \%$. Within a total of 154 theses that can be examined, it wasn't found studies that ethnographic research method which is in the interpretative research. When examined the results of the three highest rates in this theme, relationship between skills of gifted and talented individuals with $18.12 \%$, differences between gifted and talented individuals and non-gifted and talented individuals with $11.25 \%$ and require education of families which have gifted and talented individuals with $11.25 \%$. In the research carried out by Gross and van Vliet (2014), it has been indicated that, there is a relationship between creativity, analytical thinking, perception-attention control and higher level thinking of gifted and talented individuals and these skills are emphasized that it should be supported. 